\title{
A Framework for Identifying Knowledge Management Advantages Based on Meta-synthesis Method
}

Seyyed Mohammadbagher Jafari ${ }^{1}$ Assistant Professor, Department of Industrial and Financial Management, Faculty of Management and Accounting, Farabi Campus of Tehran University, Qom, Iran, (Corresponding Author).

Mahdi Shammi Zanjani ${ }^{2}$ Associate Professor, Department of IT Management, Faculty of Management, Tehran University, Iran.

Seyyed Mohammad Mahmoodi ${ }^{3}$ Associate Professor, Department of Industrial and Financial Management, Faculty of Management and Accounting, Farabi Campus of Tehran University, Qom, Iran.

Hossein Yekkeh ${ }^{4}$ Ph.D Student, Systems Management, Faculty of Management and Accounting, Farabi Campus of Tehran University, Qom, Iran.

\begin{abstract}
Today, knowledge is an invaluable resource which should be dynamically and smartly sought by any organization intending to achieve competitive advantage. The present research aims to identify and classify the advantages of establishing knowledge management It was carried out by using the meta-synthesis method. To reach this end, databases of articles containing those advantages and released between 2000 through 2019 were identified and categorized. Finally, 34 qualitative researches were selected. Then, the advantages were broken into three categories: advantages for the business, for the employees and for the customers and the market. Using confirmatory factor analysis, the suggested framework was approved. Based on the obtained results, the advantages for the business have the highest factorial load in the model; the advantages for the personnel and the customers and the market fall in the second and third places, respectively.
\end{abstract}

Keywords: Knowledge Management, Knowledge Management Advantages, Meta-synthesis Method, Structural Equations Modeling, Confirmatory Factor Analysis.

\footnotetext{
1.sm.jafari@ut.ac.ir

2.shamizanjani@ut.ac.ir

3.mahmoudi@ut.ac.ir

4.hyekkeh@ut.ac.ir
} 


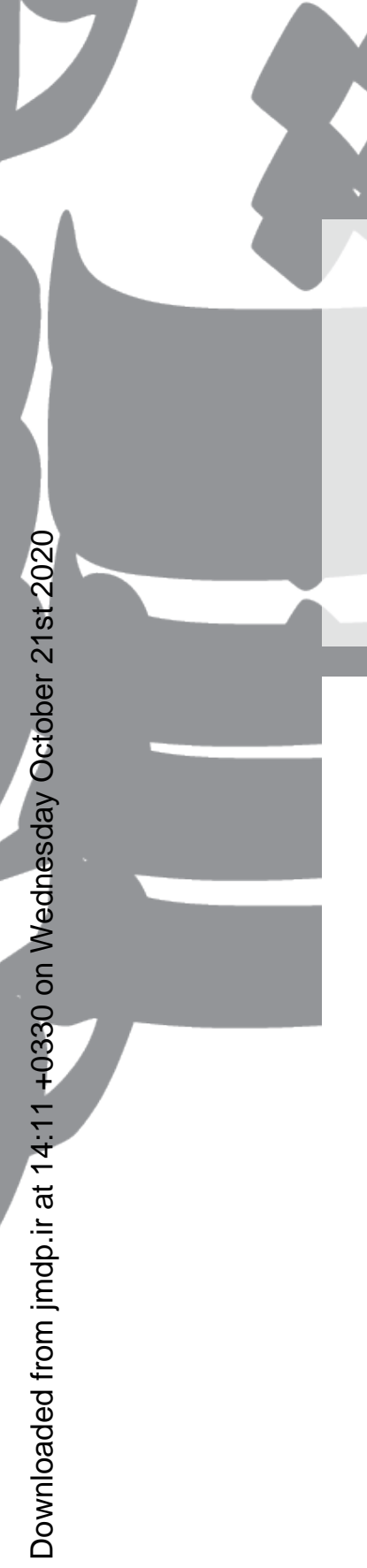

عنوان مقاله: ارائه جارجوب شناسايى منافع مديريت دانش

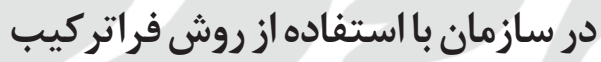

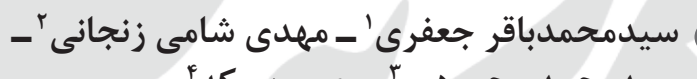

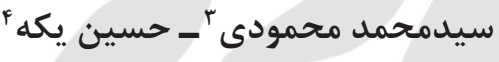

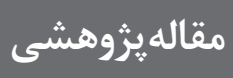

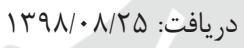

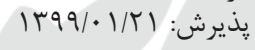

\section{جكيل:}

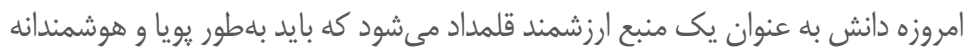

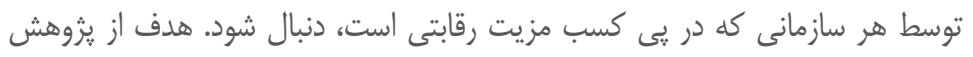

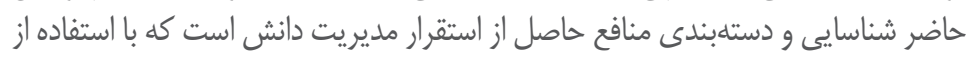

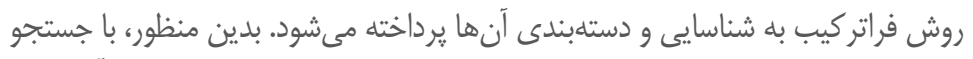

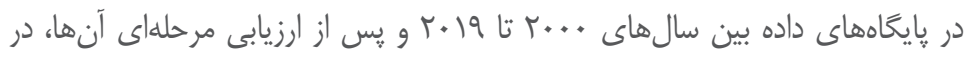

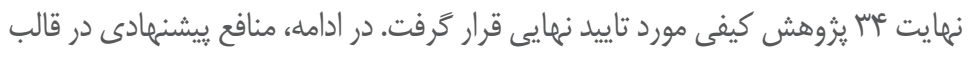

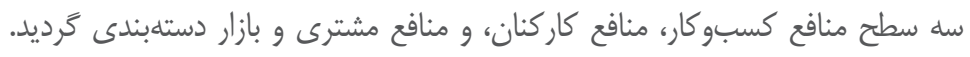

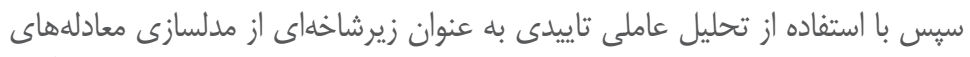

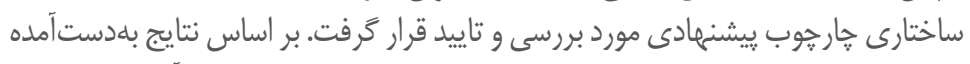

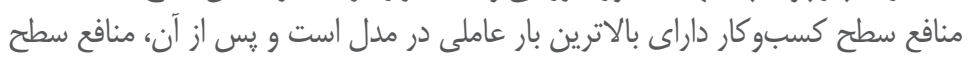

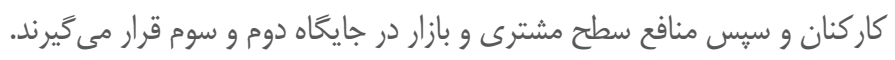
كليدوازهها: مديريت دانش، منافع مديريت دانش، روش فراتر كيب،

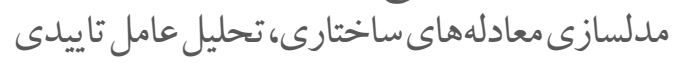

ا. استاديار كروه مديريت صنعتى و مالى، دانشكده مديريت و حسابدارى، يرديس فارابى دانشكاه تهران، قم، ايران sm.jafari@ut.ac.ir

(نويسندهمسئول). (1) (1) (1)

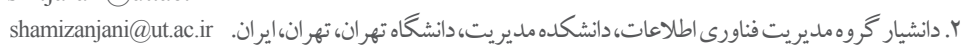

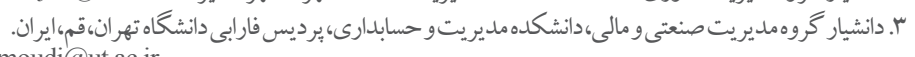
mahmoudi@ut.ac.ir

F. أشجوى دكترى مديريت سيستمها، دانشكده مديريت وحسابدارى، يرديس فارابى دانشگاه تهران،قم،ايران. hyekkeh@ut.ac.ir 


\section{مقدمه}

مديريت دانش يك اصل بنيادين است و مديريت و حفظ حسابشده منابع دانش مىتواند به ارزشافزوده سازمانها كمك كند (McIver \& Lepisto, 2017). بدون شك، با وجود اين كهيت تعدادى از سازمانها يذيراى مديريت دانش هستند، اما همه آنها قادر نيستند كه آن را به نها نها موفقيتآميزى اجرا كنند و از آن منتفع شوند. اجراى مديريت دانش يك فرايند راهبردى است و نيازمند آن است كه توسط يك مجموعه دقيق و بلطور مداوم هدايت شود (Mehralian et al., 2018). موفقيت در اجراى مديريت دانش تا حد زيادى به سنجش خروجىهاى مديريت دانش بستخى دارد. آنجه كه اكنون بيشتر نمايان مىشود اين موضوع است كه شركتهايى كه فكر مى كنند در سنجش خروجىهاى مديريت دانش داراى بهترين عملكرد هستند، در آن موضوع خوب عمل نمى كنند. در واقع، سازمانها گرايش دارند علاوه بر كمّيت، ارزش يولى ابتكارهاى مديريت دانش مدري را نيز بسنجند. سازمانها به منظور دستيابى به اهداف مديريت دانش بايد ساختارهايى براى سنجش خروجىهاى مديريت دانش ايجاد نمايند. با اين همه، تلاش مديران بايد در جهت ايجاد باد باد يك خارجوب معيار براى سنجش خروجىهاى مديريت دانش براى بيشينهسازى منافع بالقوه مديريت دانش باشد (Tabrizi et al., 2011). با وجود منافع بالقوهاى كه مىتوان با بهرهبردارى مديرى

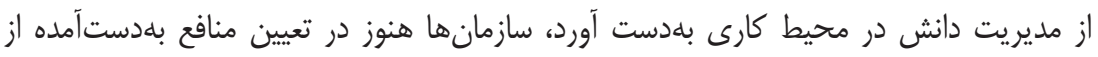

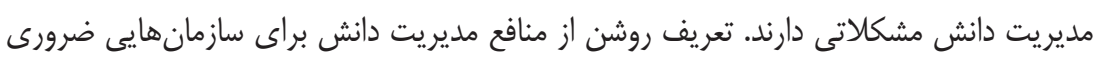
به نظر مىرسد كه به تعهد بيشتر و مشاركت كاركنان در اقدامهاى مديريت دانش توجه دارند. به علاوه، يك فهم درست از منافع مديريت دانش به درك بهتر اهداف مديريت دانش منجر مى

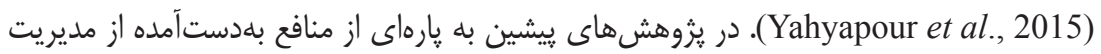
دانش در سازمانها اشاره مىشود (McIver \& Lepisto, 2017; Egbu et al., 2005) Choy et al., 2006; Anantatmula \& Kanungo, 2006 دانش، يزوهشهاى رو به رشدى موانع مديريت دانش را بررسى مى كنند و مخالفتهايى درباره تاثير مديريت دانش بر خروجىهاى متفاوت عملكردى سازمانى دارند و معتقدند كه تعدادى از

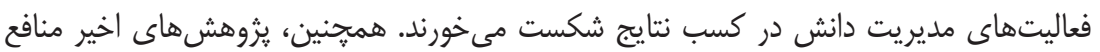

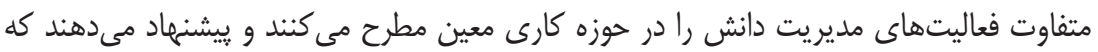


برخى از فعاليتهاى مديريت دانش مفيد نيست و حتى مىتواند عملكرد را در حوزههاى معين بازدارد (McIver \& Lepisto, 2017). تعيين و تعريف منافع مديريت دانش و خلق سازو كارى كه

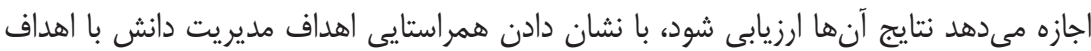
كسبوكار، يك شكاف مهم در يزوهشهاى مديريت دانش است. به باور برخى ثزوهشگران ارزيابى مديريت دانش به عنوان يك موضوع غايب، نهتنها به دليل اين حقيقت توصيف مىشود كه دانش نامحسوس است، بلكه به دليل جگَّنَى تعريف منافع مديريت دانش توسط ادبيات، بسيار

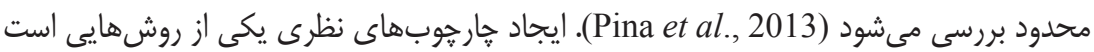

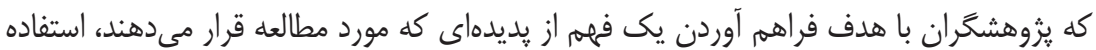

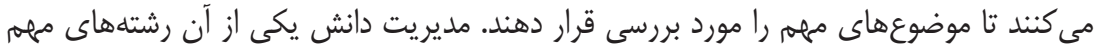

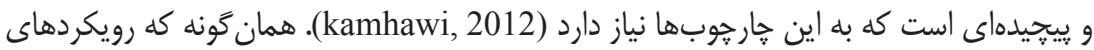
جديد بلهور مداوم در اين حوزه در حال معرفى هستند، يك جارجوب بهروز بهرب براى حفظ دانش يثرهشگَران و كارگزاران و مديران سازمانها ضرورى است. با توجه به اين كه در يزوهشهاى ييشين بيشتر به صورت موردى به بررسى خروجىها، تاثير، مزيت يا موفقيت مديريت دانش

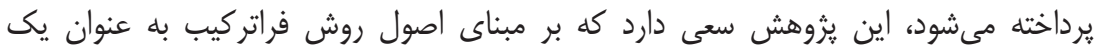
روش مناسب براى شناسايى منافع، با فراهم كردن يك نخرش نظاممند و با تركيب يافتههاى يثوهشهاى كيفى به ارائه و توسعه يك جار جوب جديد اقدام كند و از اين راه، دانش جارى را ارتقا

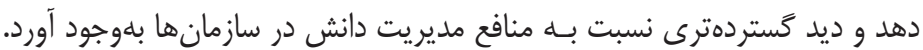

\section{مبانى نظرى ثئوهش}

حوزه مديريت دانش يك تنوع گستردهاى از رشتهها شامل فلسفه، نظريه مديريت، علم شناختى، علم اجتماعى، علم مديريت، علم اطلاعات و بلهازگى هوش مصنوعى را در بر مى گيرد و اين به دامنه گستردهاى از تعاريف، خارجوبها، و گَونهشناسىها منتج مىشود. در حقيقت، با وجود محبوبيت مديريت دانش، يك تعريف ساده براى شفافيت در دسترس وجود ندارد (McIver \& Lepisto, 2017) طرحريزىشده فعاليتها و فرايندها براى توانمندسازى دانش براى افزايش رقابتيذيرى با استفاده بهتر و خلق منابع دانش فردى و جمعى تعريف مى كند. مديريت دانش و سرمايه فكرى در ميان

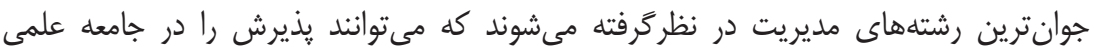


بلددست آورند (Dženopoljac et al., 2016). براهما و ميشرا' (ها • ا)، مبانى مديريت دانش را به

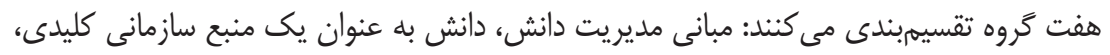
فناورىهاى مديريت دانش، خروجىهاى مديريت دانش، نقش فرهنى سازمانى در عملكرد مبتنى

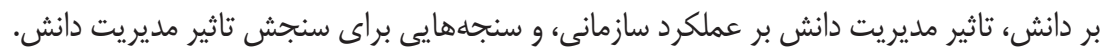

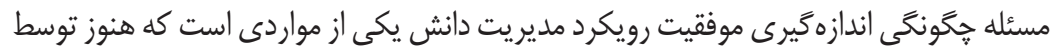
سازمانها، يزوهشكران، و مشاوران مديريت مورد بررسى قرار مى گيرد (De Gooijer, 2000).

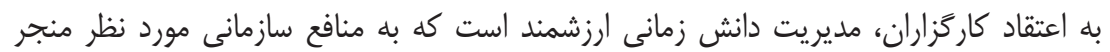

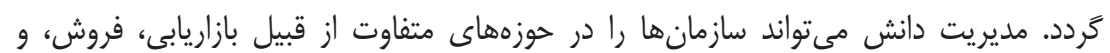

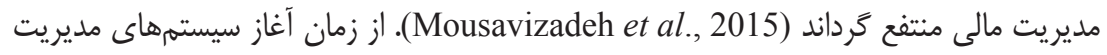

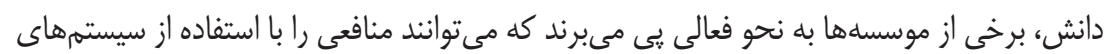
مديريت دانش بهدست آورند. موفقيت سيستمهاى مديريت دانش به ارزشكارى إنى منافع سيستم

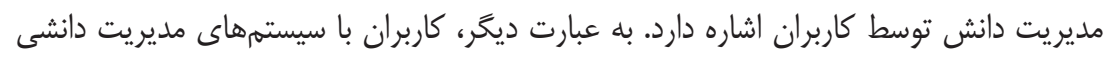

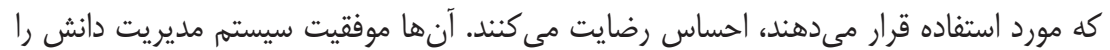
برحسب منافع كلى كه دريافت مى كنند، تشخيص مى دهند. مدلهاى بلوغ مديريت دانش بر نياز به همراستايى مديريت دانش با اهداف كسبو كار متمركز

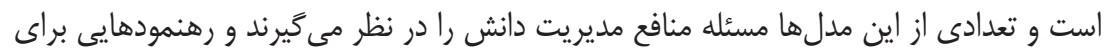

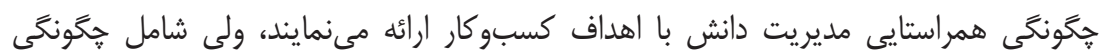

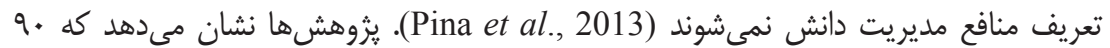

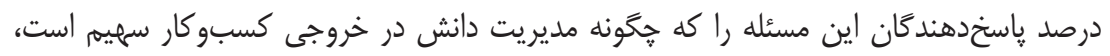

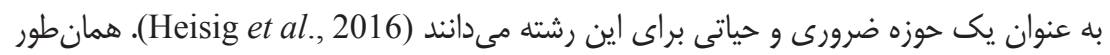

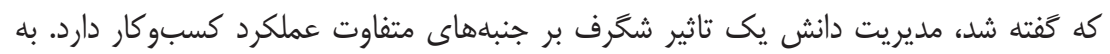

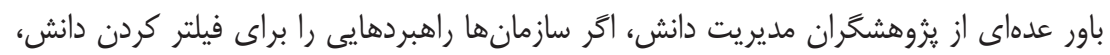

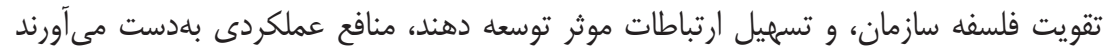
(Gupta \& Chopra, 2018). به همين جهت، برنامههاى مديريت دانش به تعيين عوامل حياتى براى كسب شاخصهاى عملكردى نياز دارد. همجِنين، اين برنامها بايد فرايند مديريت

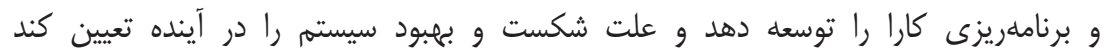

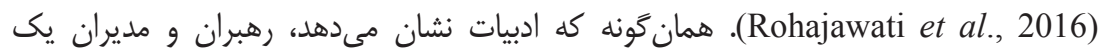


نقش اساسى در طراحى و اجراى راهبرد شركت دارند و از آنجايى كه اين راهبردها مديريت دانش را نيز شامل مىشود، پِس آنها انتظار دارند كه از آن براى منفعت شركت استفاده كنند.

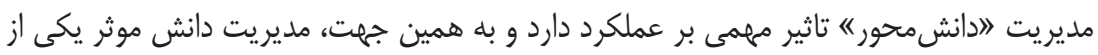
ملاحظههاى مديران كسبوكار معاصر است (Dayan et al., 2017). سرمايه كذارى در برنامههاى مدئ

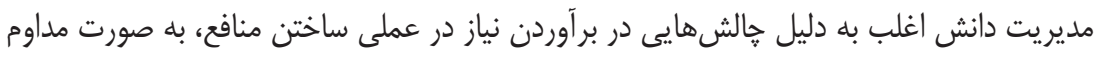

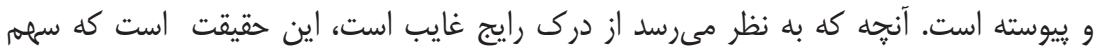

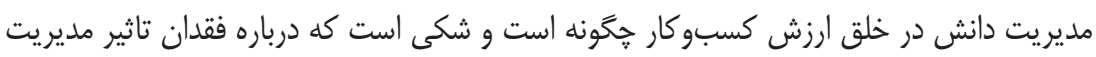

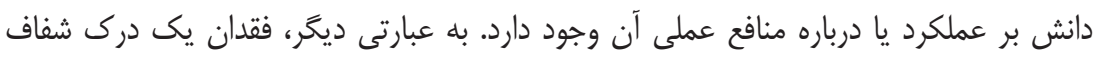

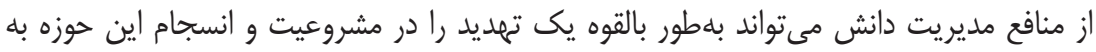

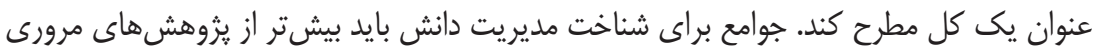

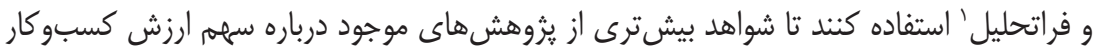

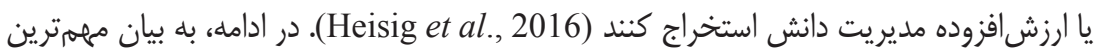
يزوهشهاى انجامشده در زمينه منافع حاصل از مديريت دانش براى سازمانها و تاثير مديريت

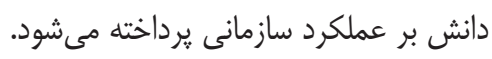

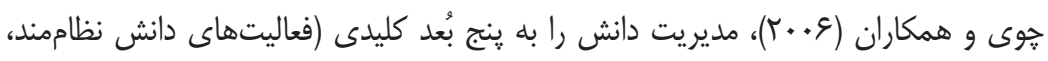
توسعه كاركنان، رضايت مشتريان، رابطه بيرونى خوب، و موفقيت سازمانى) دستهبندى مي كنتند.

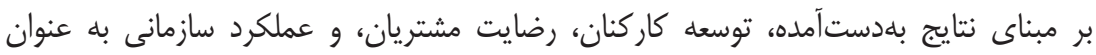
شاخصهاى معمول خروجى هاى عملكرد مديريت دانش در سازمان تعيين مىشوند. آنانتاتمولا و

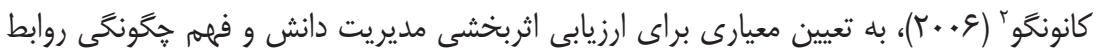

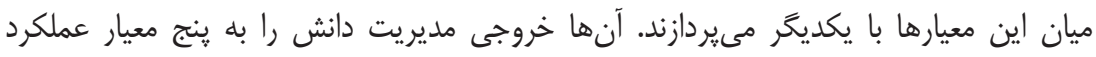

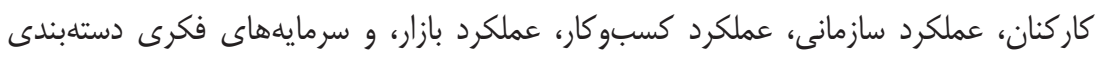

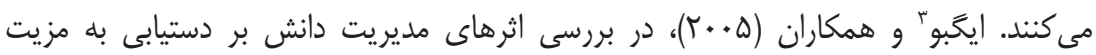

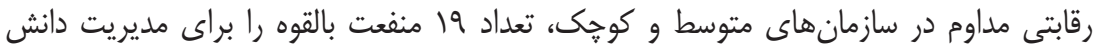

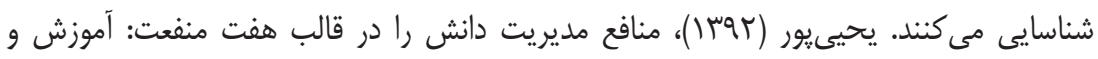

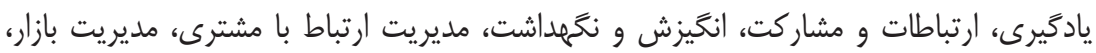

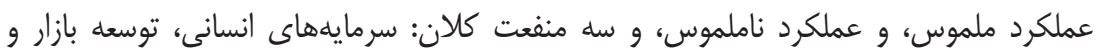

1. Meta-analysis

2. Anantatmula \& Kanungo

3. Egbu 
روابط مشترى، و عملكرد سازمانى تقسيمبندى مى كند. رييسى وانانى و همكاران (Vوسו)، عملكرد

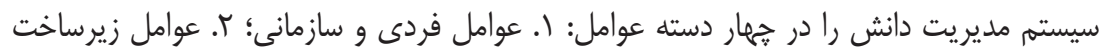

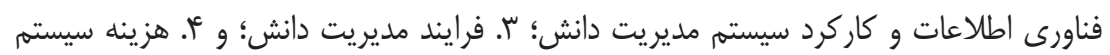
مديريت دانش معرفى مى كنند.

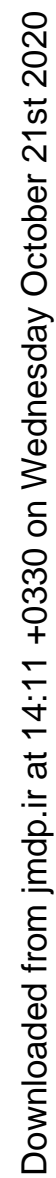

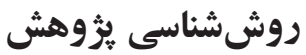

در اين يزوهش، فراتر كيب به عنوان يك روش مناسب براى دستيابى به يك تركيب جامع از عوامل

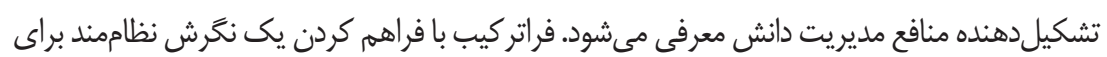
يُوهشكران، از طريق تركيب يُوهشهاى كيفى مختلف به كشف موضوعها و استعارههاى جديد و

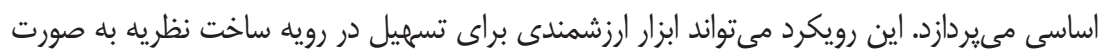

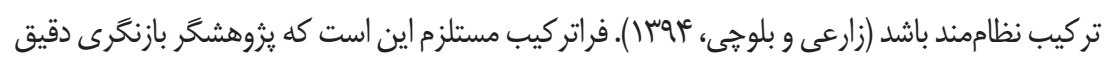

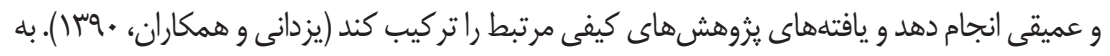

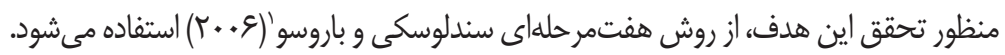

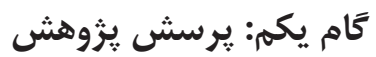

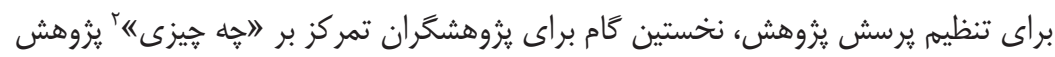

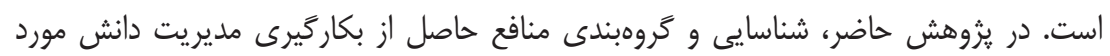

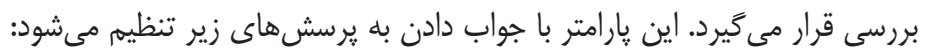

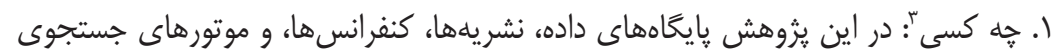

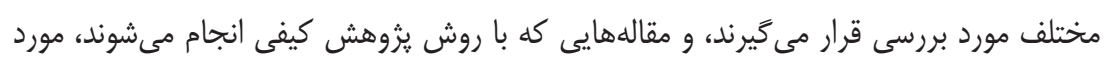
تحليل قرار مى گيرند.

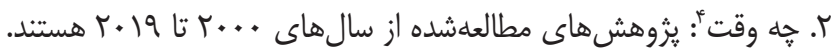

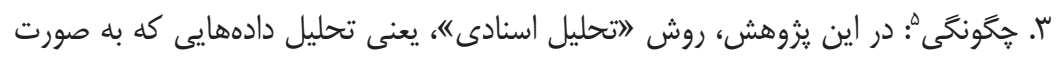
ثانويه هستند، مورد استفاده قرار مى ثيرد.

1. Sandelowski \& Barroso

2. What

3. Who

4. When

5. How 


\section{كَام دوم: بررسى متون به صورت نظاممند}

در اين مرحله، بر جستجوى نظاممند يُروهشهاى منتشرشده در بايخاههاى مختلف تمركز مىشود. همجنين، كليدواثههاى مرتبط انتخاب مىشوند. در اين بزوهش كليدواثمهايى مانند

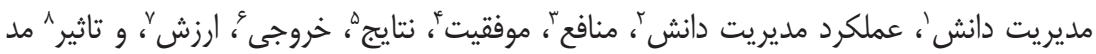

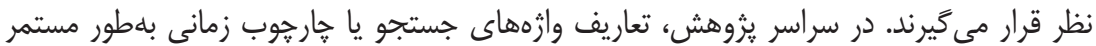

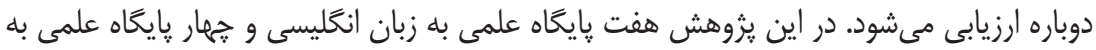

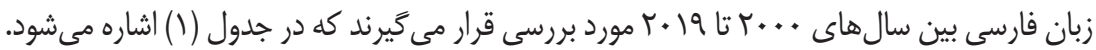

\begin{tabular}{|c|c|c|c|}
\hline مقالات يافتشده & يايخاه داده فارسى & مقالات يافتشده & يايخاههاى داده انخليسى \\
\hline- & Civilica & 9 & IEEE \\
\hline - & Magiran & $\Delta V$ & Science Direct (Elsevier) \\
\hline 4 & Irandoc & Tr & Springer \\
\hline \multirow[t]{4}{*}{-} & Noormags & $11 r$ & Emerald \\
\hline & & 0 & ProQuest \\
\hline & & זr & Taylor \& Francis \\
\hline & & 14 & Sage \\
\hline
\end{tabular}

\section{كام سوم: انتخاب مقالههاى مرتبط}

در اين كام، يزوهشكران در هر بازبينى تعدادى از مقالهها را به دليل نامرتبط بودن رد مى كنند. فرايند بازبينى به اين صورت انجام مى گيرد كه با توجه به يارامترهاى مختلفى مانند عنوان، هكيده،

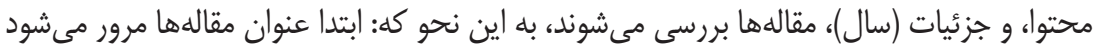

1. Knowledge Management

2. Knowledge Management Performance

3. Benefits

4. Success

5. Result

6. Outcome

7. Value

8. Impact 
و آنهايى كه با يرسش و هدف يُوهش تناسبى ندارند، حذف مىشوند. در مرحله بعد، خكيده

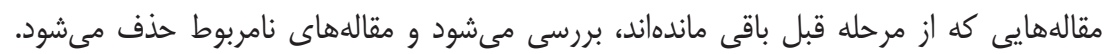

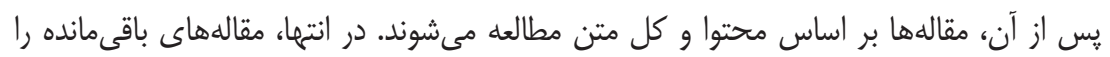
دوباره با دقت بررسى مى شوند و آنهايى كه به لحاظ روش يزوهش نامرتبط (مانند يزوهشهايى

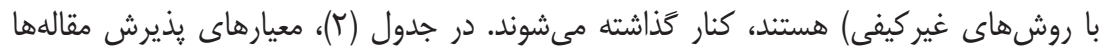

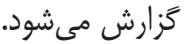

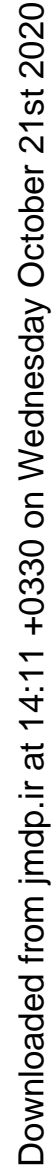

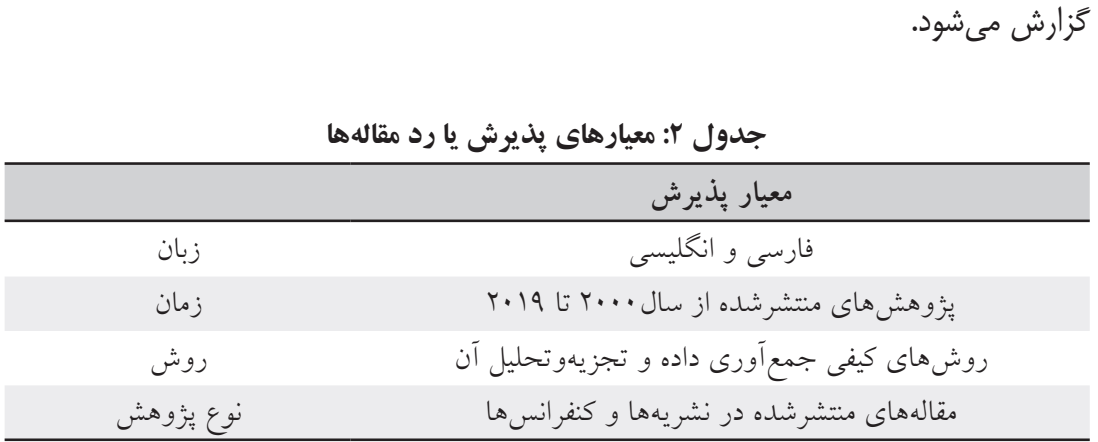

در نهايت، تعداد مقالههاى باقىمانده وارد كام بعدى روش فراتركيب مىشوند. در شكل (()، خلاصهاى از فرايند ارائهشه به همراه نتايج بهدستآمده مشاهده مى شود.
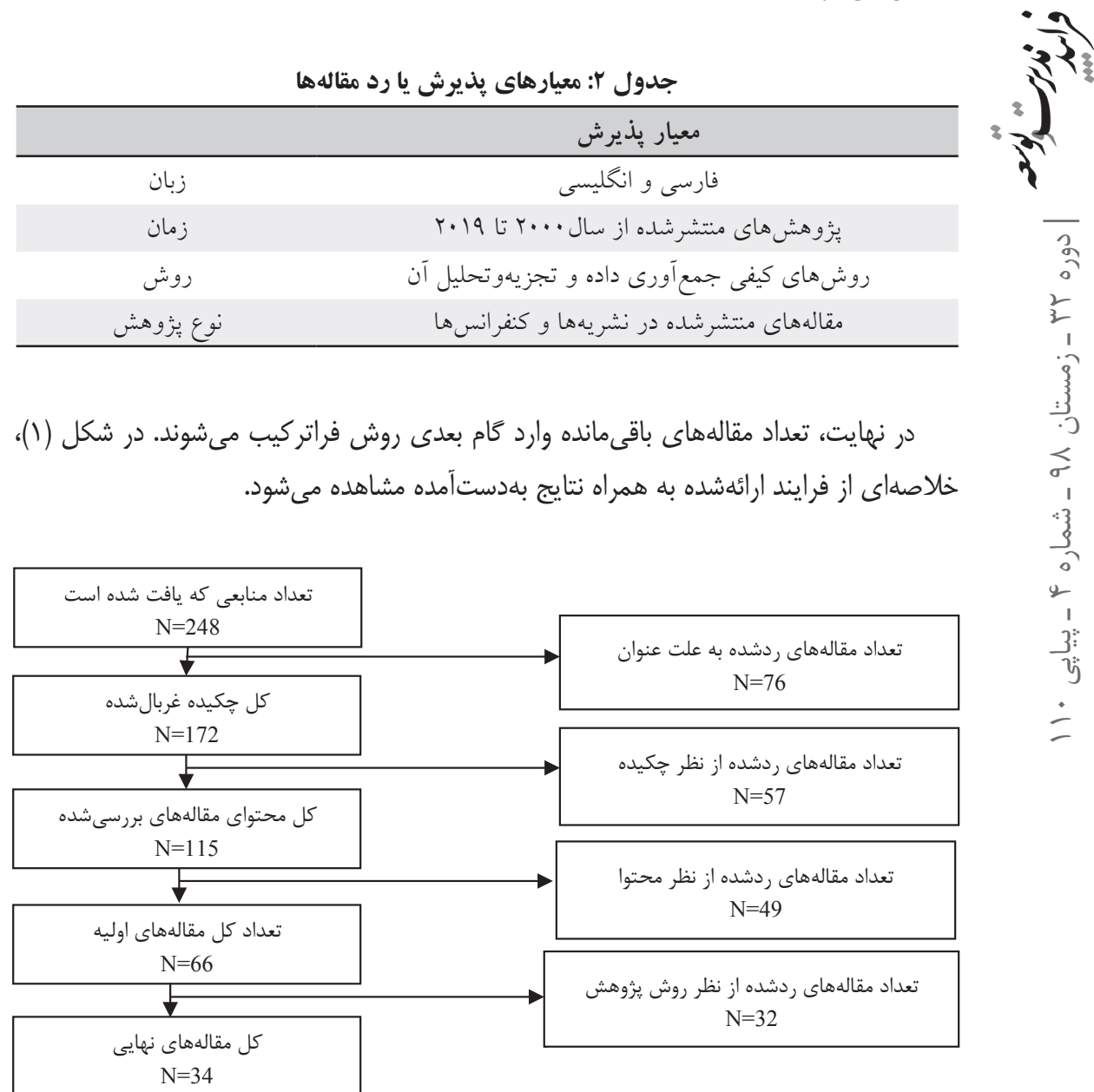


\section{كام جههارم: استخراج نتايج}

در اين مرحله، محتواى مقالهها بهدقت مطالعه مىشود و شاخصهاى اساسى استخراج

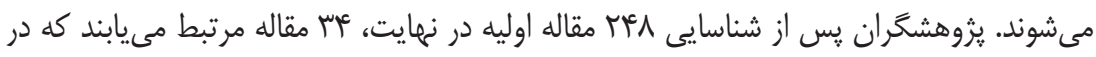
نتيجه سوع شاخص در قالب لالبُعد مورد شناسايى قرار مى گئيرد.

\section{كام ينجم: تجزيلوتحليل، و تلفيق يافتههاى كيفى}

هدف روش فراتركيب ايجاد تفسير يكيار خه و جديدى از يافتههاست. در طول تجزيهوتحليل، موضوعها يا تمهايى' جستجو مىشود كه در ميان يزوهشهاى موجود در روش فراتركيب يديدار

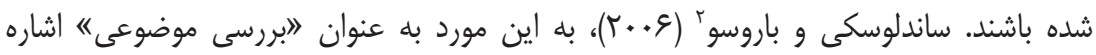

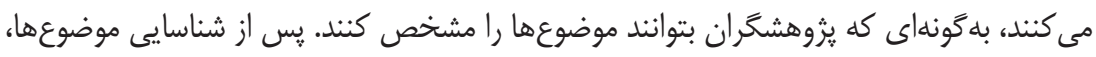

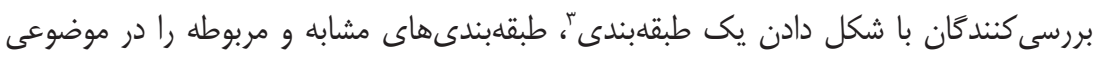

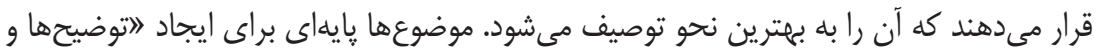
مدلها، نظريهها يا فرضها《 ارائه مىدهند (Sandelowski \& Barroso, 2006).

\section{كام ششه: حفظ كنتر كيفيت}

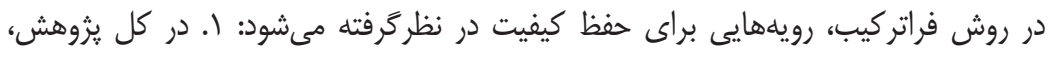

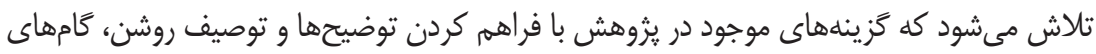

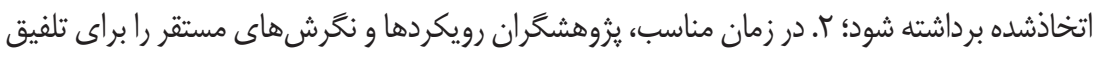

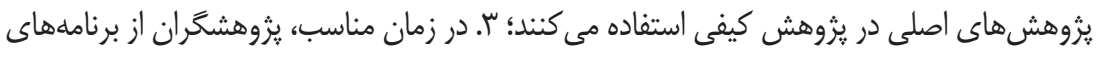

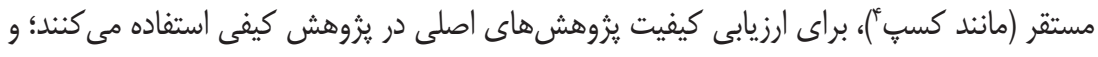

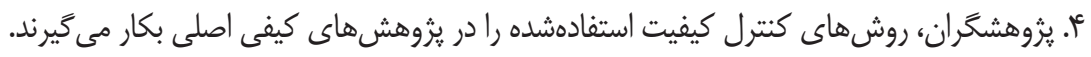

\section{كَام هفتم: ارائه يافتهها}

در اين مرحله از روش فراتركيب، يافتهاى حاصل از مراحل قبل ارائه مىشوند. در ادامه، منافع

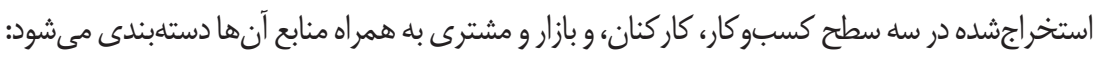

1. Themes

2. Sandelowski \& Barroso

3. Subcategory

4. CASP 


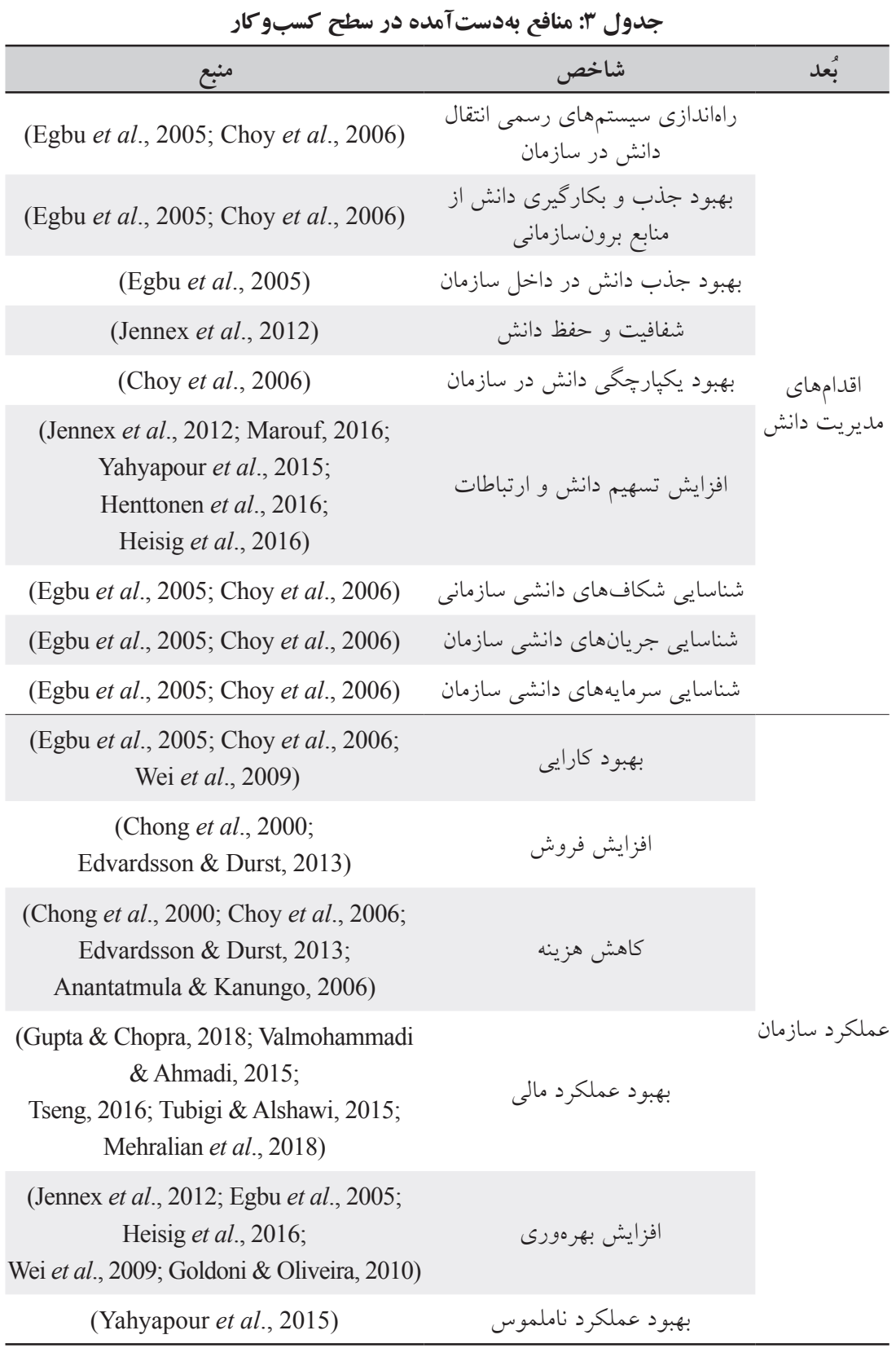


ادامه جدول r: منافع بهدست آمده در سطح كسبو كار

بُعد

(Lee et al., 2012;

Ferraresi et al., 2012; Fallatah, 2018;

Heisig et al., 2016; Yahyapour et al., 2015;

$$
\text { ارتقاى عملكرد سازمان }
$$

Shehata, 2015)

(Vakharia et al., 2018)

$$
\text { افزايش اثربخشى }
$$

(Chong et al., 2000)

$$
\text { بهبود مديريت يروزه }
$$

(Goldoni \& Oliveira, 2010)

$$
\text { كاهش دوباره كارى }
$$

(Goldoni \& Oliveira, 2010)

كاهش زمان جرخه توليد

(Kamhawi, 2012; Edvardsson \& Durst, 2013;

افزايش خلاقيت و نو آورى Ferraresi et al., 2012; Cabrilo \& Dahms, 2018;

Elmorshidy, 2018)

(Anantatmula \& Kanungo, 2006;

Heisig et al., 2016; Choy et al., 2006;

Tubigi \& Alshawi, 2015)

(Goldoni \& Oliveira, 2010;

يادگيرى

سازمانى،

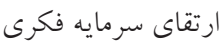

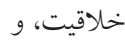

نوآورى

McIver \& Lepisto, 2017; Lee et al., 2012; ارتقاى سطح يادگيرى سازمانى

Heisig et al., 2016; Edvardsson \& Durst, 2013)

(Egbu et al., 2005; Heisig et al., 2016; Jennex et al., 2012)

$$
\text { افزايش مزيت رقابتى }
$$

(Ferraresi et al., 2012;

Tubigi \& Alshawi, 2015)

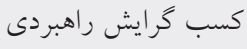

(Egbu et al., 2005; Goldoni \& Oliveir, 2010;

Choy et al., 2006 ; Heisig et al., 2016)

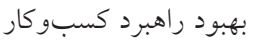
رقابتى

(Anantatmula \& Kanungo, 2006; Choy et al., 2006; Egbu et al., 2005) 
ادامه جدول rا: منافع بهدست آمده در سطح كسبو كار

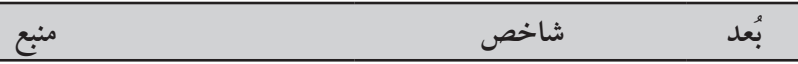

(Egbu et al., 2005; Choy et al., 2006;

Goldoni \& Oliveira, 2010)

(Wei et al., 2009; Vakharia et al., 2018)

توسعه فرهنگ نو آورى

(Kamhawi, 2012)

$$
\text { افزايش انعطافيذيرى }
$$

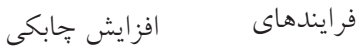

(Tubigi \& Alshawi, 2015;

Valmohammadi \& Ahmadi, 2015;

Tseng, 2016; Mehralian et al., 2018;

بهبود فر ايند داخلى كسبو كار

Gupta \& Chopra, 2018)

جدول †: منافع بلدست آمده در سطح كار كنان

\begin{tabular}{lll}
\hline & شُعد \\
\hline
\end{tabular}

(Chong et al., 2000; Giampaoli et al., 2017;

Goldoni \& Oliveira, 2010;

افزايش توان حل مسئله

Heisig et al., 2016)

(Egbu et al., 2005; Choy et al., 2006) بهبود آموزش حين خدمت به كاركنان

(Anantatmula \& Kanungo, 2006;

Choy et al., 2006; Wei et al., 2009)

$$
\text { آموزش و يادگيرى پِاسخكويى سريع تر به مسائل كليدى }
$$
و توان حل مسئله

(Anantatmula \& Kanungo, 2006;

Wei et al., 2009; Choy et al., 2006)

$$
\text { بهبود تصميم گيرى }
$$

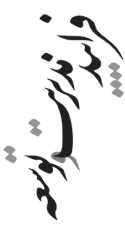

(Choy et al., 2006;

Goldoni \& Oliveira, 2010)

$$
\text { بوبود توانايى يادگيرى كاركنان }
$$


ادامه جدول †ُ: منافع بلدست آمده در سطح كاركنان

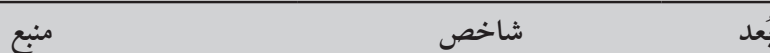

(Edvardsson \& Durst, 2013;

Choy et al., 2006; Wei et al., 2009; بهبود جذبو نحهداشت كاركنان

Yahyapour et al., 2015)

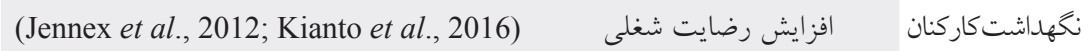

(Egbu et al., 2005; Choy et al., 2006;

Yahyapour et al., 2015)

بهبود و افزايش انخيزش

(Anantatmula \& Kanungo, 2006;

Choy et al., 2006;

بهبود مهارتهاى كاركنان

Edvardsson \& Durst, 2013)

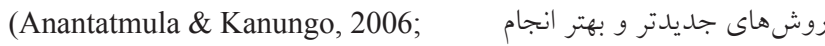

Choy et al., 2006)

كارها

(Egbu et al., 2005)

بهبود كيفيت نيروى كار سازمان

(Anantatmula \& Kanungo, 2006;

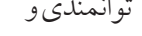

عملكردكار كنان

Tseng, 2016; Choy et al., 2006; Abualoush et al., 2018;

تو انمندسازى كار كنان

Edvardsson \& Durst, 2013)

(Masa'deh et al., 2017;

Abualoush et al., 2018)

ارتقاى بهبود عملكرد كاركنان

(Chong et al., 2000; Choy et al., 2006;

Anantatmula \& Kanungo, 2006)

(Chong et al., 2000;

Anantatmula \& Kanungo, 2006)

بهبود ارتباطات ميان كاركنان

(Anantatmula \& Kanungo, 2006;

Choy et al., 2006; Goldoni \& Oliveira, 2010)

ارتقاى مشاركت ميان كاركنان

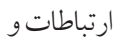

مشاركت كاركنان 
جدول ه: منافع بهدست آمده توسط مشترى و بازار

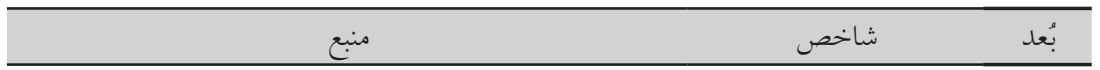

(Chong et al., 2000; Liu et al., 2016;

Egbu et al., 2005)

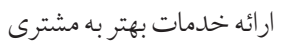

(Egbu et al., 2005)

$$
\text { تسهيم دانش با مشتريان }
$$

(Egbu et al., 2005; Goldoni \& Oliveira, 2010) توسعه ارتباط با مشترى

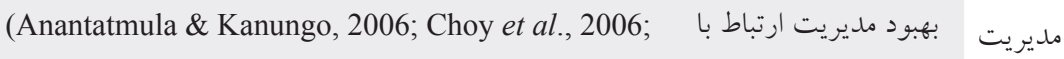

Yahyapour et al., 2015)

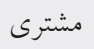

مشترى مل ميريت

Edvardsson \& Durst, 2013;

Mehralian et al., 2018; Valmohammadi \& Ahmadi, 2015; فزايش رضايت مشترى

Goldoni \& Oliveira, 2010; Gupta \& Chopra, 2018)

خلق ارزش بيشتر براى (Anantatmula \& Kanungo, 2006; Choy et al., 2006)

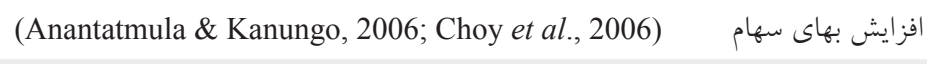

(Anantatmula \& Kanungo, 2006; Choy et al., 2006) افزايش سهم بازار

(Anantatmula \& Kanungo, 2006; Choy et al., 2006; ورود به بازارهاى جديد
Tubigi \& Alshawi, 2015)

(Anantatmula \& Kanungo, 2006; Choy et al., 2006) إزايش اندازه بازار

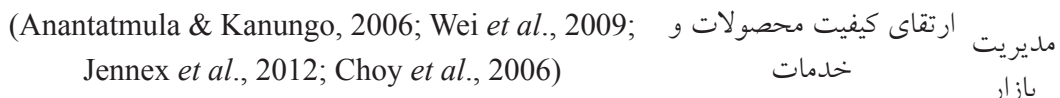

(Anantatmula \& Kanungo, 2006; Choy et al., 2006)

بهبود و توسعه محصولات

(Goldoni \& Oliveira, 2010;

Edvardsson \& Durst, 2013)

كسترش ارتباط با

عرضه كنند كان

(Yahyapour et al., 2015)

مديريت بازار

(Yahyapour et al., 2015)

بهبود عملكرد بازار

در ادامه، جار جوب نهايى منافع استخراجشده مديريت دانش كه مشتمل بر سو منفعت شناسايىشده

است، در سه سطح منافع كسبوكار (اقدامهاى مديريت دانش، عملكرد سازمان، يادگيرى سازمانى و و

خلاقيت و نوآورى، راهبرد و مزيت رقابتى، و فرايندهاى سازمانى)، منافع كاركنان (آموزش و يادكيرى و

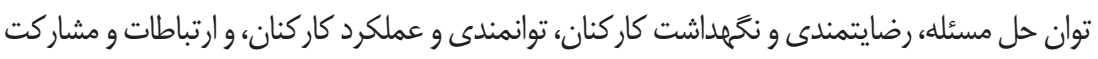


كاركنان)، و منافع بازار و مشترى (مديريت مشترى و مديريت بازار) در جدول (() نشان داده مىشود. جدول ع: جارجوب مفهومى ثزوهش

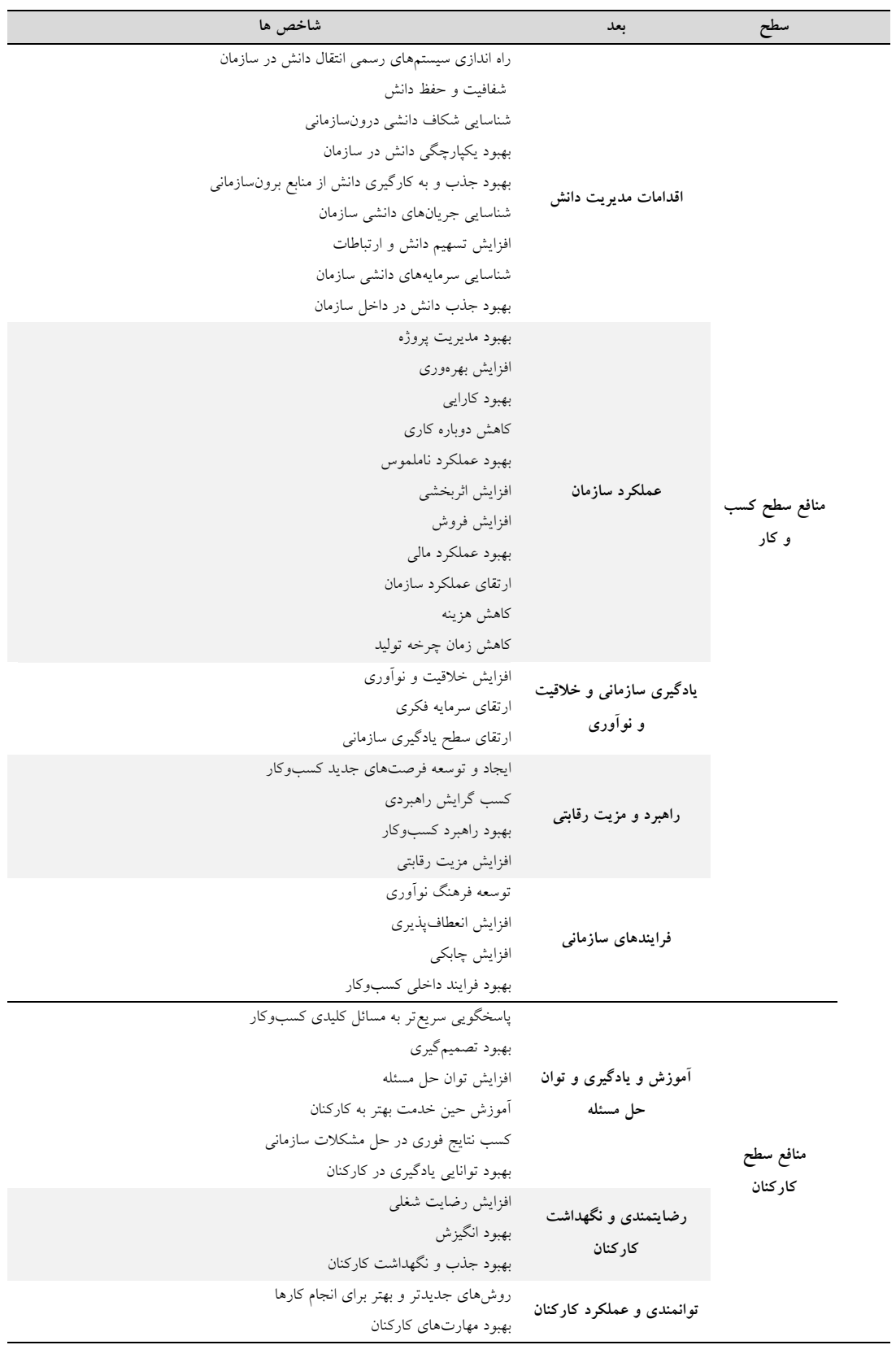


ادامه جدول ؟: جارجوب مفهومى يخوهش

\begin{tabular}{|c|c|c|}
\hline شاخص ها & بعد & سطح \\
\hline \multicolumn{3}{|l|}{ ت ت توانمندسازى كاركنان } \\
\hline \multicolumn{3}{|l|}{ بهبود كيفيت نيروى كار سازمان } \\
\hline \multicolumn{3}{|l|}{ ارتقاى بهبود عملكرد كاركنان } \\
\hline ارتقاى مشاركت بيشتر ميان كاركنان & $-<120-0$ & \\
\hline بهبود ارتباط ميان كاركنان & (1) & \\
\hline \multicolumn{3}{|l|}{ به اشتر اك كذارى بهترين شيوهها } \\
\hline \multicolumn{3}{|l|}{ ارائه خدمات بهتر به مشترى } \\
\hline \multicolumn{3}{|l|}{ تسهيم دانش با مشتريان } \\
\hline \multicolumn{3}{|l|}{ توسعه ارتباط با مشترى } \\
\hline \multicolumn{3}{|l|}{ افزايش رضايت مشترى } \\
\hline \multicolumn{3}{|l|}{ بهبود مديريت ارتباط با مشترى } \\
\hline \multicolumn{3}{|l|}{ خلق ارزش بيشتر براى مشترى } \\
\hline \multicolumn{3}{|l|}{ ورود به بازارهاى جديد } \\
\hline \multicolumn{3}{|l|}{ افزايش سهم بازار } \\
\hline \multicolumn{3}{|l|}{ مديريت بازار } \\
\hline \multicolumn{3}{|l|}{ افزايش بهاى سهام } \\
\hline ارتقاى كيفيت محصولات و خدمات & مديريت بازار & \\
\hline \multicolumn{3}{|l|}{ بهبود عملكرد بازار } \\
\hline \multicolumn{3}{|l|}{ افزايش اندازه بازار } \\
\hline \multicolumn{3}{|l|}{ بهبود توسعه محصولات جديد } \\
\hline \multicolumn{3}{|l|}{ كسترش ارتباط با عرضه كندكان } \\
\hline
\end{tabular}

\section{تجزيهوتحليل يافتهها}

تجزيلوتحليل در دو بخش انجام مىشود. بخش نخست تاييد يرسشنامه طراحىشده توسط

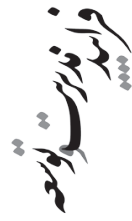

ส

등 يثرهشگًران مبتنى بر تجزيلوتحليل كيفى است و در بخش دوم، به تاييد مدل آمارى با استفاده از تكنيك تحليل عاملى تاييدى مىرسد. نخستين گام در تعيين روايى يرسشنامه طراحى شده، بررسى روايى محتواست. در اين روش، برسشهاى برسشنامه در اختيار متخصصان يا برخى از آزمودنى ها قرار مى يَيرد

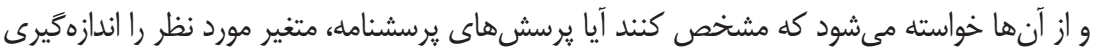

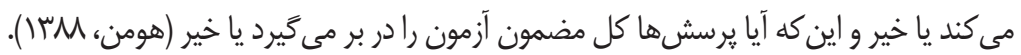




\section{بررسى يايايى و روايیى آزمون ساختهشده}

براى بررسى روايى مضمون آزمون به دو شيوه عمل مىشود:

$$
\text { شاخص نسبت روايى مضمون' (CVR): }
$$

براى محاسبه اين شاخص از نظر ها نفر از استادان، اعضاى هيئتعلمى، و كارشناسان

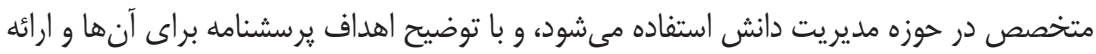

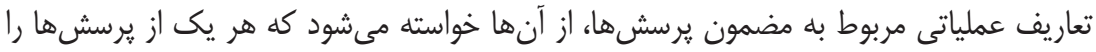
بر اساس طيف سهبخشى ليكرت "كويه ضرورى است)، "كويه مفيد است ولى ضرورى نيستها،

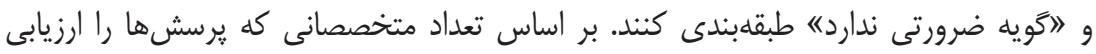

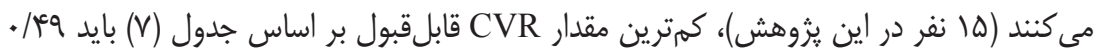
باشد. קنانجه مقدار CVR محاسبهشده كمتر از ميزان مورد نظر با توجه به تعداد متخصصصان

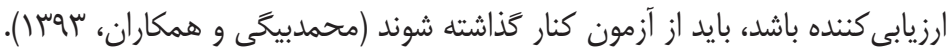
جدول Y: كمينهُ CVR قابلقبول بر اساس تعداد متخصصان نمرهزذار

\begin{tabular}{|c|c|c|c|c|c|}
\hline CVR مقدار & تخدصاد & مقدار CVR & متخصصان & مقدار CVR & تخدصاد \\
\hline$\cdot / r V$ & ro & $\cdot 109$ & 11 &.$/ 99$ & 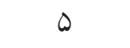 \\
\hline r & r. & $\cdot 109$ & IT &.$/ 99$ & 4 \\
\hline$\cdot / \mu_{1}$ & ro & $\cdot / O F$ & ir &.$/ 99$ & v \\
\hline \multirow[t]{3}{*}{$\cdot / \pi q$} & 4. & $\cdot / 01$ & 14 & $\cdot / V Q$ & $\wedge$ \\
\hline & & $\cdot / 49$ & 10 & $\cdot / \mathrm{VA}$ & 9 \\
\hline & & D MT & $r$. & $.19 T$ & 1. \\
\hline
\end{tabular}

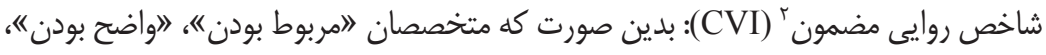

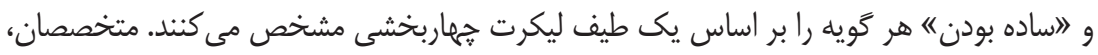

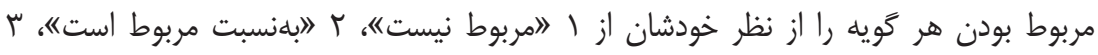

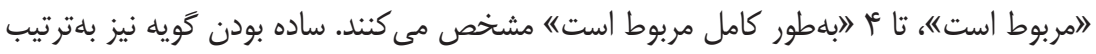

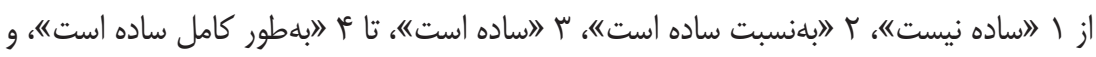

1. Content Validity Ratio

2. Content Validity Index 


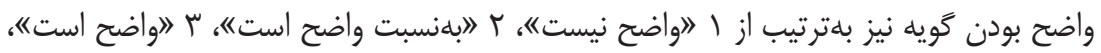

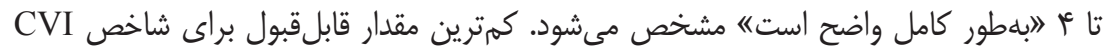

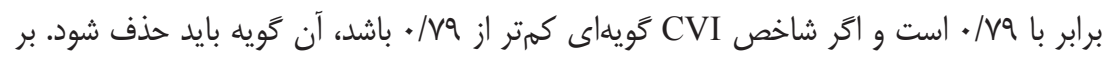

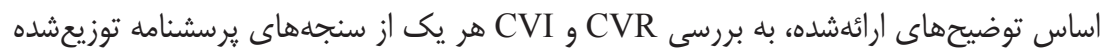

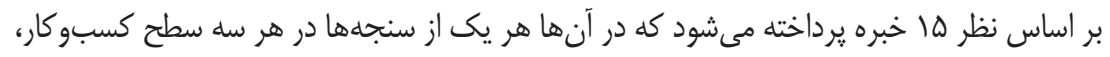

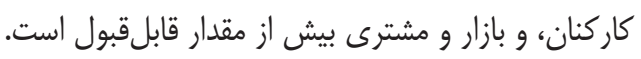

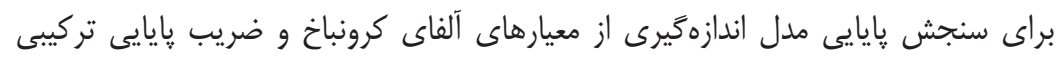

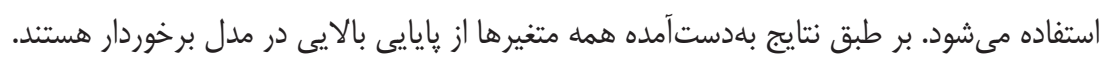

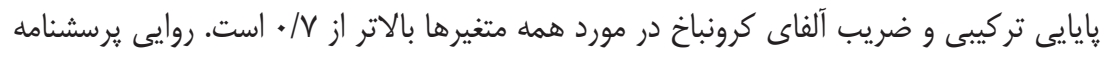

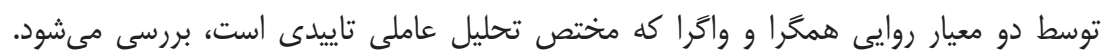

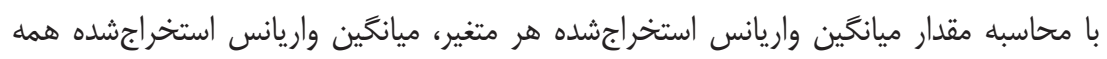

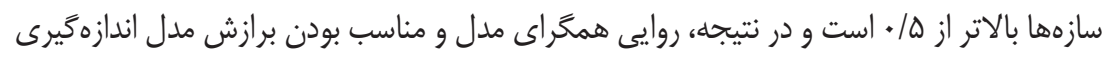

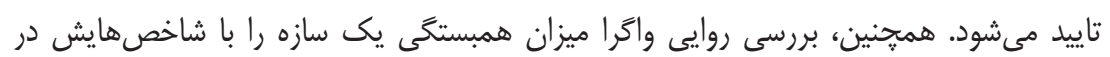

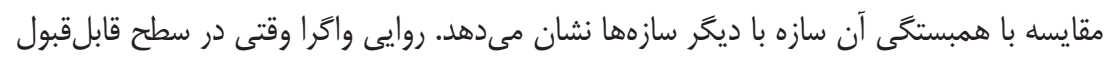

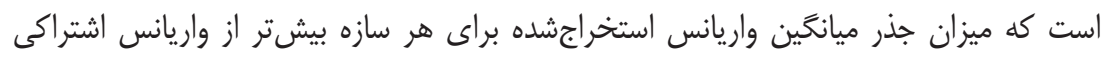

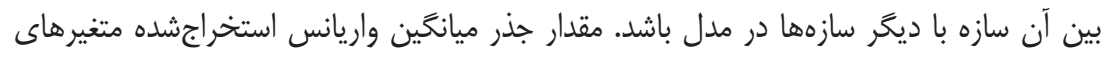

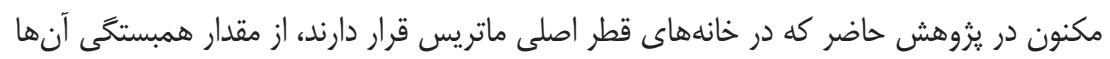

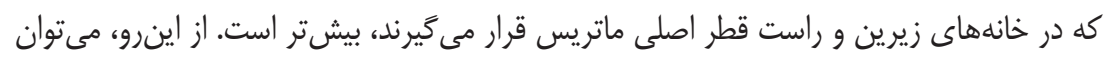

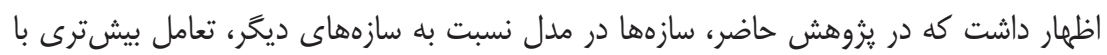

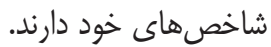

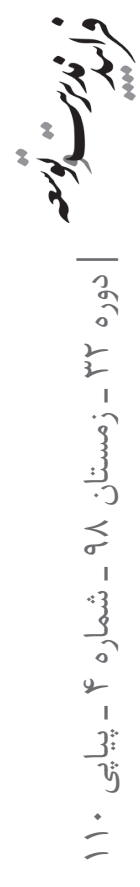


جدول 1: بارهاى عاملى استانداردشده در مدل تاييدى اصلاحشده سازه سطح كسبو كار

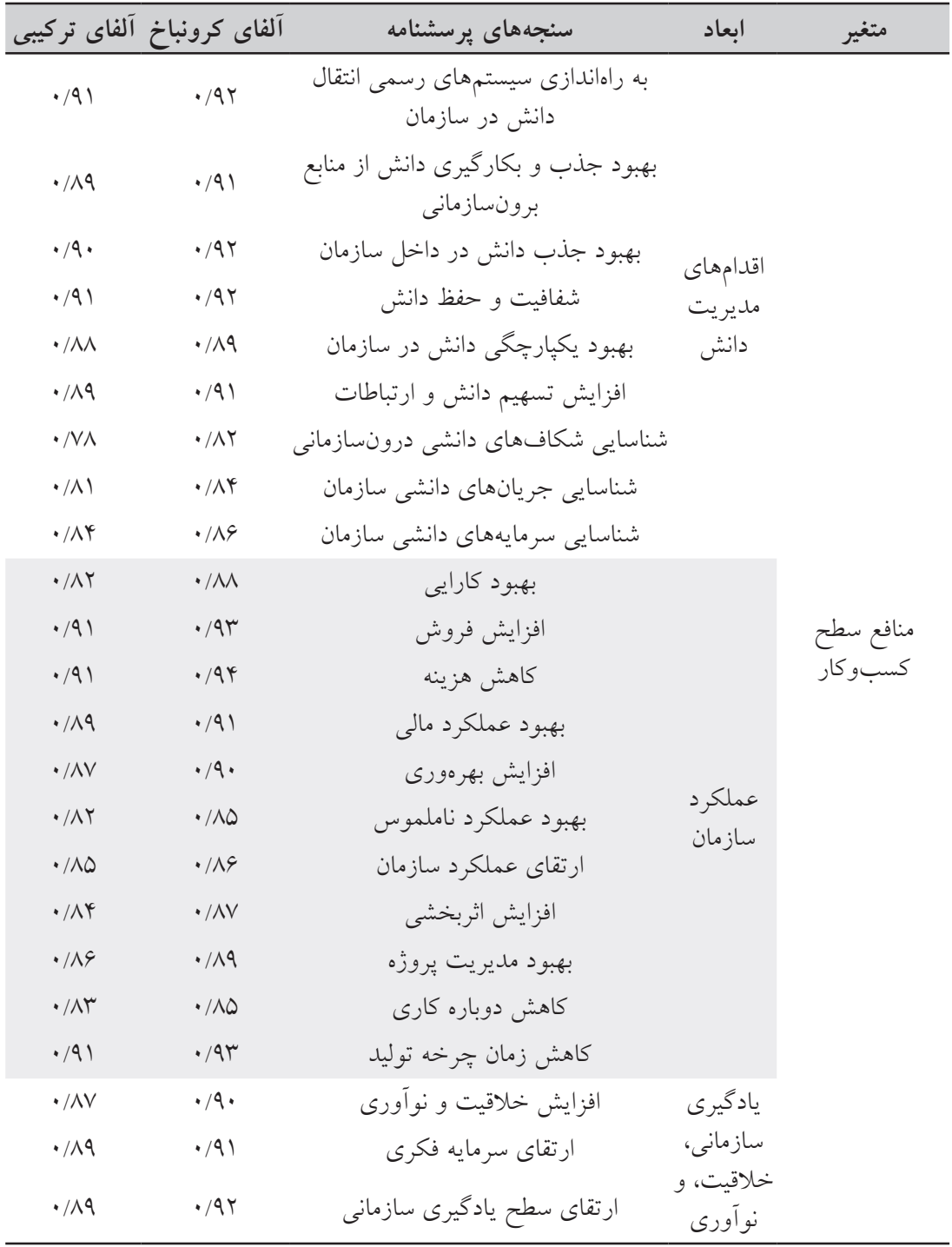




\begin{tabular}{|c|c|c|c|c|}
\hline آلفاى تركيبى & آلفاى كرونباخ & سنجههاى برسشنامه & ابعاد اد & متغير \\
\hline$\cdot / 91$ & $\cdot / 9 \pi$ & افزايش مزيت رقابتى & \multirow{4}{*}{ ور مزيت } & \multirow{8}{*}{ كسافع سطح } \\
\hline$\cdot / \wedge 9$ & $\cdot / 91$ & كسب گرايش راهبردى & & \\
\hline$\cdot / 9$ & $\cdot / 94$ & بهبود راهبرد كسبو كار & & \\
\hline$\cdot / \wedge$ & $\cdot / \Lambda F$ & ايجادوتوسعه فرصت كساى جديد & & \\
\hline 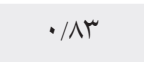 & $\cdot / \wedge 9$ & توسعه فرهنخ نو آورى & \multirow{4}{*}{ فرايندهاى } & \\
\hline$\cdot / \wedge \varphi$ & $\cdot / \Lambda \Lambda$ & افزايش انعطاف يذيرى & & \\
\hline$\cdot / \Lambda F$ & $\cdot / 9$ & افزايش جِابكى & & \\
\hline$\cdot / 94$ & $\cdot / 90$ & بهبود فرايند داخلى كسبو كار & & \\
\hline
\end{tabular}

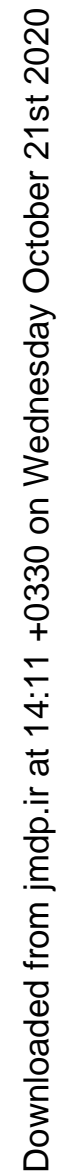

جدول 9: بارهاى عاملى استانداردشده در مدل تاييدى اصلاحشده سازه سطح كاركنان

\begin{tabular}{|c|c|c|c|c|}
\hline تر كيبى آلفاى & كرونباخ & سنجه هاى ير سشنامه & 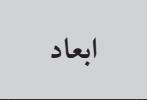 & 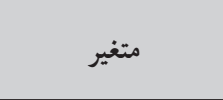 \\
\hline$\cdot / \Lambda$ & $\cdot / \wedge 9$ & افزايش توان حل مسئله & \multirow{6}{*}{ ياد آموزش و و } & \multirow{17}{*}{ منافع سطح كاركنان } \\
\hline$\cdot / 19$ & $\cdot / \Lambda \Lambda$ & آموزش در حين خدمت بهتر به كاركنان & & \\
\hline$\cdot / \Lambda 4$ & $\cdot / 9$ & پِاسخكويى سريعتر به مسائل كليدى كسبو كار & & \\
\hline.$/ 94$ & $\cdot / 90$ & بهبود تصميم گيرى & & \\
\hline$\cdot / 94$ & $\cdot / 9 V$ & بهبود توانيى يادكيرى كاركنان & & \\
\hline.$/ 91$ & $\cdot / 94$ & كسب نتايج فورى در حل مشكلات سازمانى & & \\
\hline$\cdot / 19$ & $\cdot / 9 T$ & بهبود جذب و نخهداشت كاركنان & \multirow{3}{*}{ و رضايتمندى } & \\
\hline$\cdot / \Lambda F$ & $\cdot / \wedge \vee$ & افزايش رضايت شغلى & & \\
\hline$\cdot / \mathrm{AV}$ & $\cdot / \Lambda \Lambda$ & افزايش انخيزش و نخهداشت & & \\
\hline$\cdot / 19$ & $\cdot / 19$ & بهبود مهارتهاى كاركنان & \multirow{5}{*}{ و تو عملكرد انمندى } & \\
\hline$\cdot / \mathrm{A}$ & $\cdot / 91$ & روشهاى جديدتر و بهتر براى انجام كارها & & \\
\hline$\cdot / \wedge \Delta$ & $\cdot / \wedge \mathrm{V}$ & بهبود كيفيت نيروى كار سازمان & & \\
\hline . $/ 94$ & $\cdot / 90$ & توانمندسازى كاركنان & & \\
\hline$\cdot / 19$ & $\cdot / 9 r$ & ارتقاى بهبود عملكرد كاركنان & & \\
\hline$\cdot / 91$ & $\cdot / 9 r$ & بهبود ارتباطات ميان كاركنان & \multirow{3}{*}{ و ارتباطات } & \\
\hline.$/ 91$ & $\cdot / 94$ & ارتقاى مشاركت و همكارى بيشتر ميان كاركنان & & \\
\hline.$/ 91$ & $\cdot / \Lambda \Lambda$ & بهاشتر اك كذارى بهترين شيوهها & & \\
\hline
\end{tabular}


جدول • ا: بارهاى عاملى استانداردشده در مدل تاييدى اصلاحشده سازه سطح بازار و مشترى

\begin{tabular}{|c|c|c|c|c|}
\hline آلفاى تر كيبى & آلفاى كرونباخ & سنجه هاى بر سشنامه & ابعاد - اد & 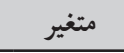 \\
\hline$\cdot / A r$ & $\cdot / \Lambda \Lambda$ & ارائه خدمات بهتر به مشترى & \multirow{6}{*}{ مشتريت } & \multirow{15}{*}{ و مشح بازع } \\
\hline.$/ 91$ & $\cdot / 94$ & تسهيم دانش با مشتريان & & \\
\hline.$/ 91$ & $\cdot / 94$ & توسعه ارتباط با مشترى & & \\
\hline$\cdot / 19$ &.$/ 91$ & بهبود مديريت ارتباط با مشترى & & \\
\hline$\cdot / A V$ & $\cdot / 9$ & افزايش رضايت مشترى & & \\
\hline$\cdot / A r$ & $\cdot / \wedge Q$ & خلق ارزش بيشتر براى مشترى & & \\
\hline$\cdot / \wedge \Delta$ & $\cdot / \wedge 9$ & افزايش بهاى سهام & \multirow{9}{*}{ مديريت } & \\
\hline$\cdot / \wedge \uparrow$ & $\cdot / \wedge \mathrm{V}$ & افزايش سهم بازار & & \\
\hline$\cdot / \wedge 9$ & $\cdot / \wedge 9$ & ورود به بازارهاى جديد (كسترش بازار) & & \\
\hline •/A & $\cdot / \wedge \Delta$ & افزايش اندازه بازار & & \\
\hline.$/ 91$ & $\cdot / 94$ & ارتقاى كيفيت محصولات و خدمات & & \\
\hline$\cdot / \wedge \mathrm{V}$ & $\cdot / 9$ & بهبود توسعه محصولات جديد & & \\
\hline$\cdot / 19$ & $\cdot / 91$ & كسترش ارتباط با عرضه كنند گان & & \\
\hline$\cdot / \wedge 9$ & $\cdot / 9 r$ & مديريت بازار & & \\
\hline$\cdot / A r$ & $\cdot / \mathrm{A}$ & بهبود عملكرد بازار & & \\
\hline
\end{tabular}

جدول 11: نتايج ميانغين واريانس استخراجشده سازههاى مدل

\begin{tabular}{|c|c|c|}
\hline AVE & ابعاد اد & متغير ل \\
\hline$\cdot / \Lambda 1$ & اقدامهاى مديريت دانش & \multirow{5}{*}{ منافع سطح كسبو كار } \\
\hline$\cdot / v 9$ & عملكرد سازمان & \\
\hline$\cdot / \Lambda$ & يادگيرى سازمانى، خلاقيت، و نو آورى & \\
\hline$\cdot / \mathrm{VA}$ & راهبرد و مزيت رقابتى & \\
\hline$\cdot / \Lambda 1$ & فر ايندهاى سازمانى & \\
\hline$\cdot / \mathrm{V} \wedge$ & آموزش و يادگيرى و توان حل مسئله & \multirow{4}{*}{ منافع سطح كاركنان } \\
\hline$\cdot / v 9$ & رضايتمندى و نخهداشت كاركنان & \\
\hline$\cdot / A r$ & تو انمندى و عملكرد كاركنان & \\
\hline - / V9 & ارتباطات و مشاركت كاركنان & \\
\hline$\cdot / \Lambda \mid$ & 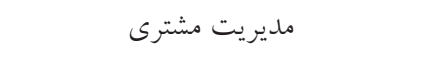 & \multirow{2}{*}{ منافع سطح بازار و مشترى } \\
\hline$\cdot / \wedge \cdot$ & مديريت بازار & \\
\hline
\end{tabular}




\section{برازش مدل ساختارى}

براى بررسى برازش مدل ساختارى با روش PLS' از ضرايب R' و Q استفاده مى شود. ضريب

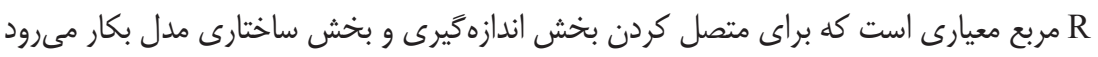

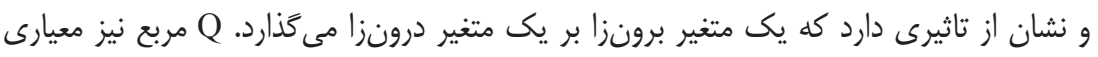

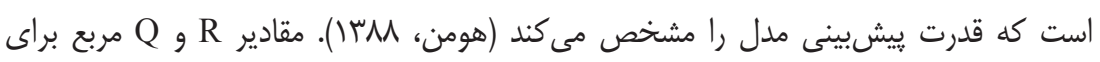

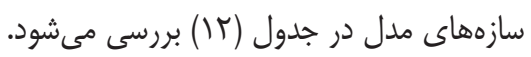

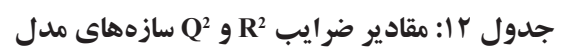

\begin{tabular}{|c|c|c|c|}
\hline $\mathbf{Q}^{2}$ & $\mathbf{R}^{2}$ & 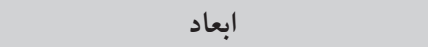 & 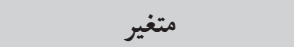 \\
\hline$\cdot$ /VTQ & $\cdot / 91 \%$ & اقدامهاى مديريت دانش & \multirow{5}{*}{ منافع سطح كسبو كار } \\
\hline $.194 \Lambda$ & - /AYK & عملكرد سازمان & \\
\hline.$|94|$ & $\cdot / \Delta r q$ & ياد گيرى سازمانى، خلاقيت، و نو آورى & \\
\hline$\cdot / V I F$ & $\cdot / 190$ & راهبرد و مزيت رقابتى & \\
\hline$\cdot 19 \cdot r$ & $\cdot / 119$ & فرايندهاى سازمانى & \\
\hline.$/ 90$ & $\cdot / \wedge \Delta$ & آموزش، يادگيرى، و توان حل مسئله & \multirow{4}{*}{ منافع سطح كاركنان } \\
\hline$\cdot 199$ & $\cdot / 19$ & رضايتمندى و نخهداشت كاركنان & \\
\hline$\cdot / \mathrm{rr}$ & $\cdot / 9 r$ & تو انمندى و عملكرد كاركنان & \\
\hline .194 & $\cdot /$ A & ارتباطات و مشاركت كاركنان & \\
\hline$\cdot / D V Y$ & - NAY & 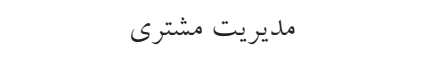 & \multirow{2}{*}{ نافع سطح بازار و مشترى } \\
\hline .1994 & . /AGK & مديريت بازار & \\
\hline
\end{tabular}

هرجه مقادير R مربع مربوط به سازههاى درونزاى يك مدل بيشتر باشد، نشاندهندة برازش

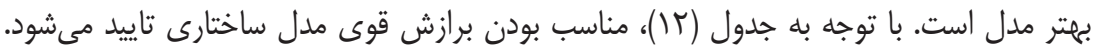

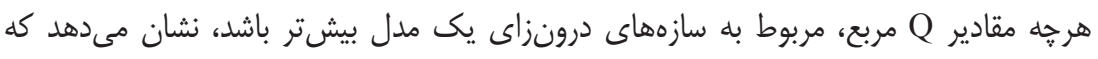

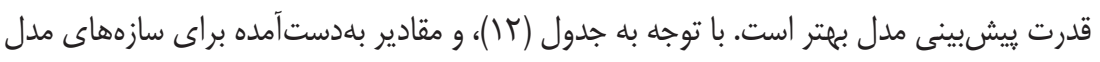

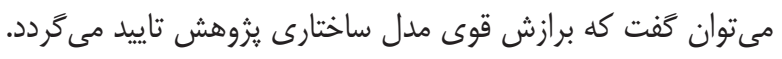

1. Partial Least Squares 


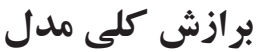

ارزيابى برازش كلى مدل با استفاده از شاخص نيكويى برازش GOF' انجام مىيذيرد كه براى

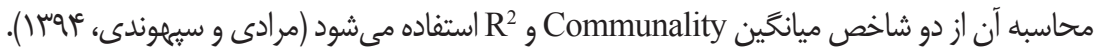

جدول با: مقادير Communality و Rدل

\begin{tabular}{|c|c|c|c|c|}
\hline GOF & $\mathbf{R}^{2}$ & Communality & ابعاد اد & 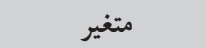 \\
\hline$\cdot / 0 \cdot 0$ & $\cdot / 411$ & $\cdot 19 \cdot 9$ & اقدامهاى مديريت دانش & \multirow{5}{*}{ كنافع سطح كار } \\
\hline . 19YT & $\cdot / \Delta T_{1}$ & $\cdot$ NTA & عملكرد سازمان & \\
\hline .1994 &.$/ 914$ & $\cdot$ NAY & يادگيرى سازمانى، خلاقيت، و نوآورى & \\
\hline $.19 M 4$ & .1919 & . $190 \mathrm{r}$ & راهبرد و مزيت رقابتى & \\
\hline$\cdot 1911$ & $\cdot 19 \cdot 0$ & .1911 & فر ايندهاى سازمانى & \\
\hline 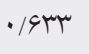 & $\cdot / \Delta K$. & $\cdot N+1$ & آموزش، يادكيرى، و توان حل مسئله & \multirow{4}{*}{ كنافع سطح } \\
\hline$\cdot N \cdot V$ & . /GYY & $\cdot / \wedge \cdots$ & رضايتمندى و نحهداشت كاركنان & \\
\hline .1901 & . /GMt & $\cdot 19 \mathrm{~V}$ & تو انمندى و عملكرد كاركنان & \\
\hline $.19 Y \Delta$ & .1919 & . & ارتباطات و مشاركت كاركنان & \\
\hline$\cdot 19 \cdot r$ & $\cdot /$ OTV & $\cdot 1919$ & 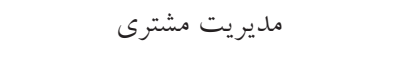 & \multirow{2}{*}{ منافع سطح بازار و } \\
\hline $.19 \mathrm{VT}$ &.$/ 9 \mu \mathrm{V}$ & $\cdot$ NIT & مديريت بازار & \\
\hline
\end{tabular}

با محاسبه شاخص نيكويى برازش مشخص مى شود كه ميزان GOF در اين مدل قابلقبول است.

\section{آزمون رتبهبندى عوامل}

تحليل عاملى تاييدى به عنوان زيرشاخهاى از مدلسازى معادلههاى ساختارى يكى روش قدرتمند براى بررسى روايى سازهّ در يخوهشهايى است كه داراى ابزار اندازهخيرى يرسشنامه با سنجههاى كمّى و كيفى هستند. زمانى كه با خند سنجه كمّى يا كيفى، يك سازه اندازهگيرى مى شود، ميزانى از همبستخى و اشتراك سنجهها در اندازه گيرى سازه مهم است. در تحليل عاملى تاييدى سنجههاى

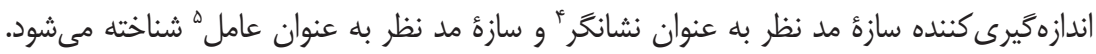

1. Goodness of Fit

2. Structural Equations Modeling

3. Construct Validity

4. Indicator

5. Factor 
نشانكرها در تحليل عامل تاييدى به صورت مشاهدهشده و عامل به صورت ينهان يا مكنون هستند.

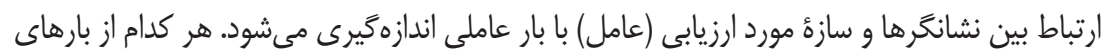

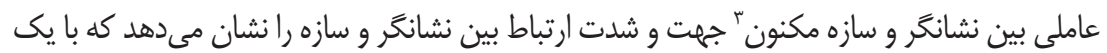

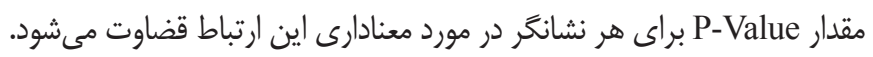

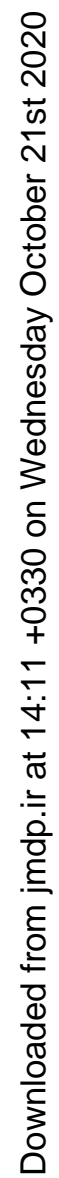

\section{طراحى مدل در نرمافزار}

در يثوهش حاضر، براى تحليل عاملى تاييدى از روش برآورد حداقل مربعهاى تعميميافته؟

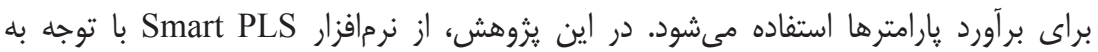

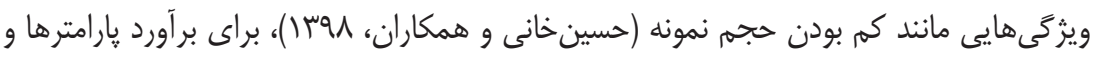
كليه محاسبههاى تحليل عاملى تاييدى سازهها استفاده مىشود.

جدول ج أ: متغيرها و كدهاى آن در نرمافزار

\begin{tabular}{|c|c|c|c|}
\hline كد & ابعاد & كد & متغير \\
\hline OL1 & اقدامهاى مديريت دانش & \multirow{5}{*}{$\mathrm{OL}$} & \multirow{5}{*}{ منافع سطح كسبو كار } \\
\hline OL2 & عملكرد سازمان & & \\
\hline OL3 & يادكيرى سازمانى، خلاقيت، و نوآورى & & \\
\hline OL4 & راهبرد و مزيت رقابتى & & \\
\hline OL5 & فر ايندهاى سازمانى & & \\
\hline WL1 & آموزش، يادگيرى، و توان حل مسئله & \multirow{4}{*}{ WL } & \multirow{4}{*}{ منافع سطح كاركنان } \\
\hline WL2 & رضايتمندى و نخهداشت كاركنان & & \\
\hline WL3 & تو انمندى و عملكرد كاركنان & & \\
\hline WL4 & ارتباطات و مشاركت كاركنان & & \\
\hline MCL1 & 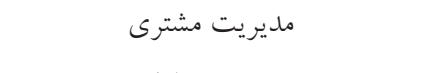 & \multirow[t]{2}{*}{ MCL } & \multirow{2}{*}{ منافع سطح بازار و مشترى } \\
\hline MCL2 & مديريت بازار & & \\
\hline
\end{tabular}

بدينترتيب، ابتدا به تاييد هر سازه و سِّ تاييد كل مدل يرداخته مىشود.

\section{Observed}

2. Latent

3. Lambda

4. Generalized Least Squares 


\section{تاييد سازه منافع سطح سازمان}

در ادامه، به بررسى آماره t مربوط به روابط سازه منافع سطح كسبو كار يرداخته مىشود.

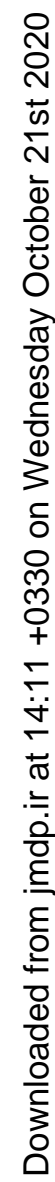

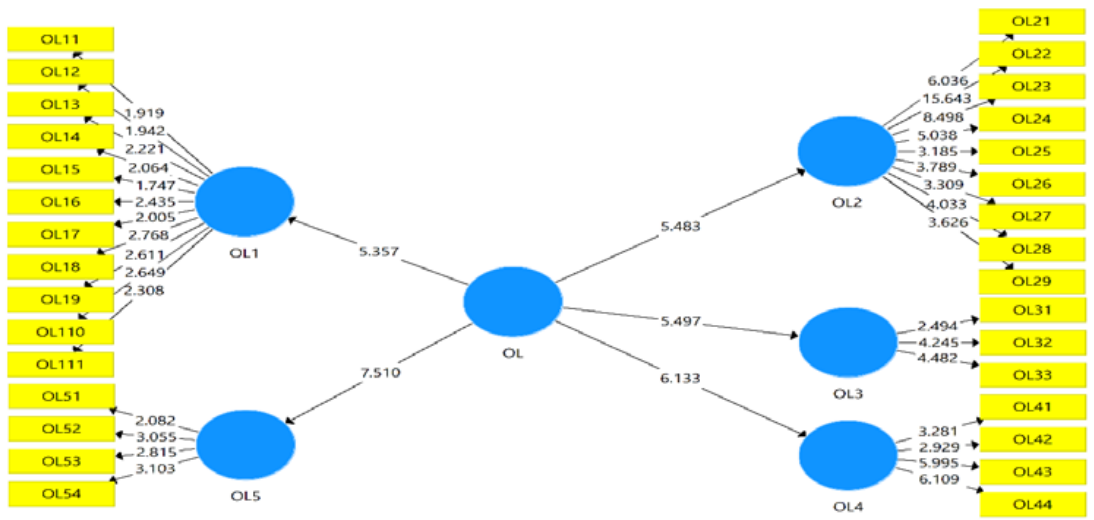

شكل r: مقدار معنادارى روابط سازه منافع سطح كسبوكار بر اساس مقادير t

همانطور كه در شكل (T) مشخص است، همه روابط در مدل مورد تاييد هستند. با توجه به اين كه روابط معنادارند، در ادامه به بررسى بارهاى عاملى سازه سطح كسبو كار يرداخته مىشود.

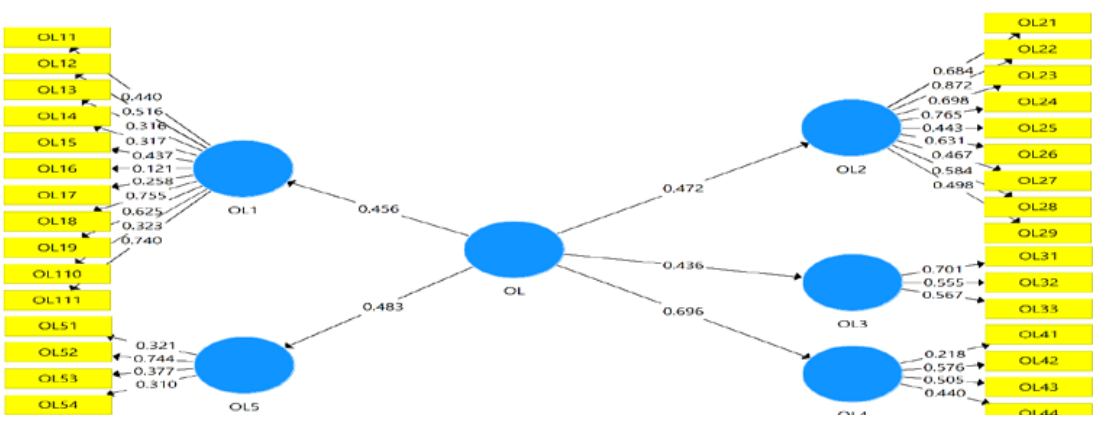

شكل "ا: ميزان بارهاى عاملى محاسبهشده در سازه منافع سطح كسبو كار

بارهاى عاملى نشان مىدهند كه سازه منافع سطح كسبو كار از ابعاد و مولفههاى شناسايىشده ساخته مى شود. 


\section{تاييد سازه منافع سطح كار كنان}

با بررسى آماره t به روابط سازه منافع سطح كاركنان يرداخته مىشود.

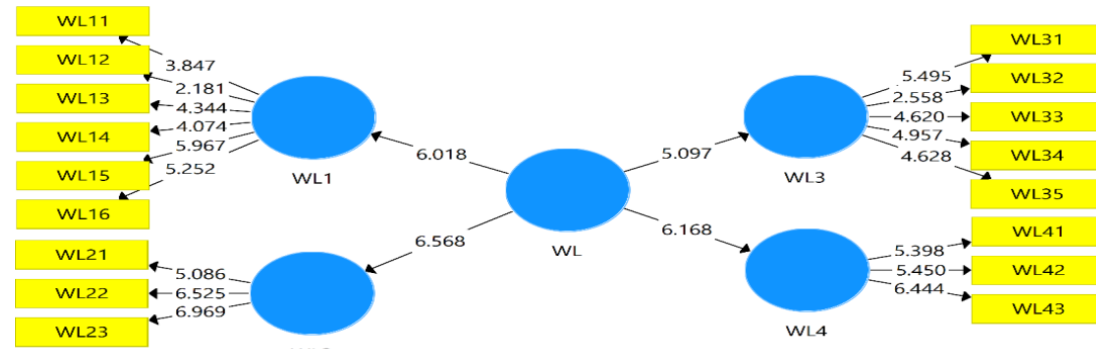

شكل †: مقدار معنادارى روابط سازه منافع سطح كار كنان بر اساس مقادير t

همه روابط در مدل تاييد مىشوند. با توجه به اين كه روابط معنادار هستند، در ادامه به بررسى بارهاى عاملى سازه سطح كاركنان يرداخته مىشود.

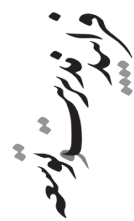

\section{بارهاى عاملى سازه سطح كاركنان برداخته مي شود.}

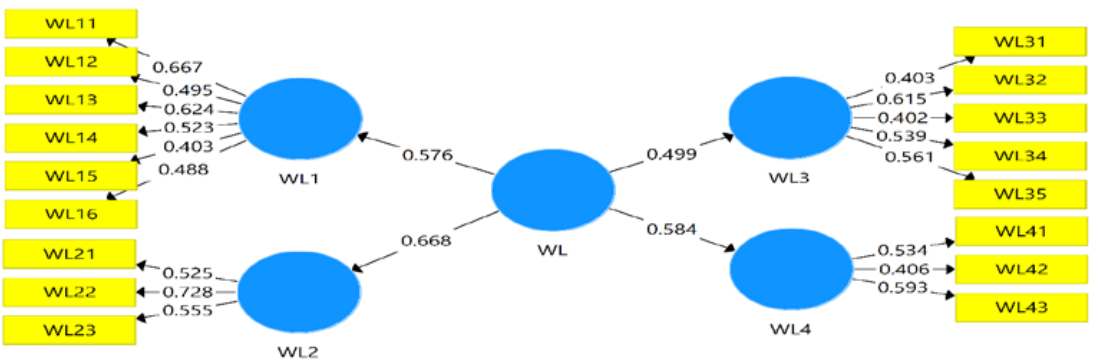

شكل ه: ميز ان بارهاى عاملى محاسبهشده در سازه منافع سطح كار كنان

همان طور كه در شكل (ه) مشخص است، بارهاى عاملى نشان مىدهند كه سازه منافع سطح كاركنان از ابعاد و مولفههاى شناسايىشده ساخته مى شود. 


\section{تاييد سازه منافع سطح بازار و مشترى}

در ادامه به بررسى آماره t مربوط به روابط سازه منافع سطح بازار و مشترى يرداخته مىشود.

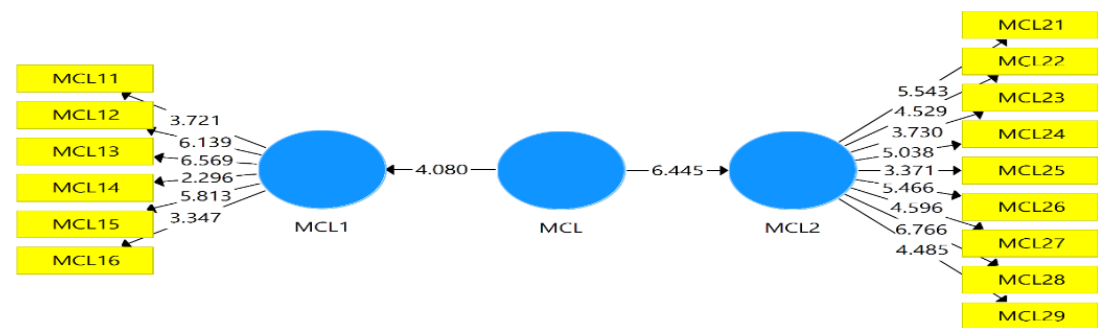

شكل \&: مقدار معنادارى روابط سازه منافع سطح بازار و مشترى بر اساس مقادير

همه روابط در مدل تاييد مىشوند. با توجه به اين كه روابط معنادار هستند، در ادامه به بررسى بارهاى عاملى سازه سطح بازار و مشترى يرداخته مىشود.

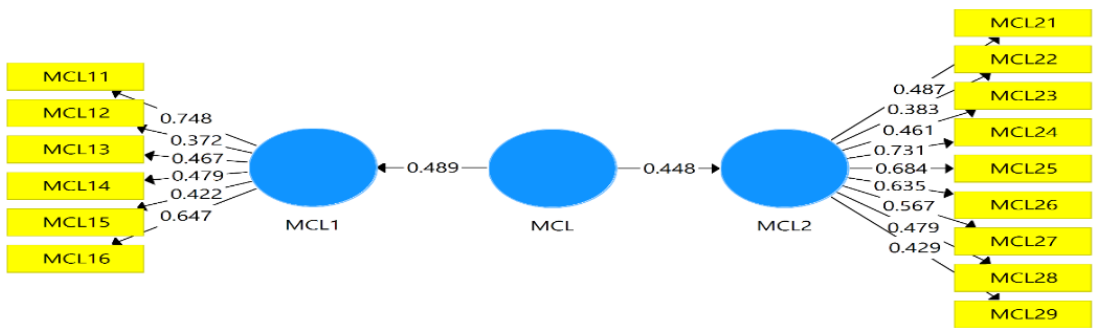

شكل \: ميزان بارهاى عاملى محاسبهشده در سازه منافع سطح بازار و مشترى

بارهاى عاملى نشان مىدهند كه سازه منافع سطح بازار و مشترى از ابعاد و مولفههاى شناسايىشده ساخته مى شود.

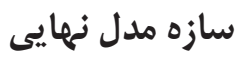

براى بررسى سازه كلى مدل متشكل از سه سازه تاييدشده قبلى، در شكل (^)، مقدار t كه نشاندهنده معنادارى رابطه ابعاد و مولفهها با متغير مورد بررسى است، نشان داده مىشود. 


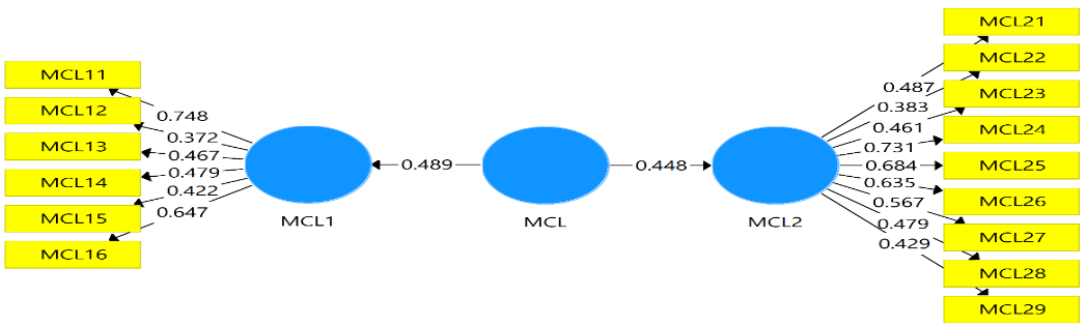

همه روابط در مدل نهايى تاييد مىشوند. با توجه به اين كه روابط معنادار هستند، در ادامه به بررسى بارهاى عاملى ثرداخته مىشود.
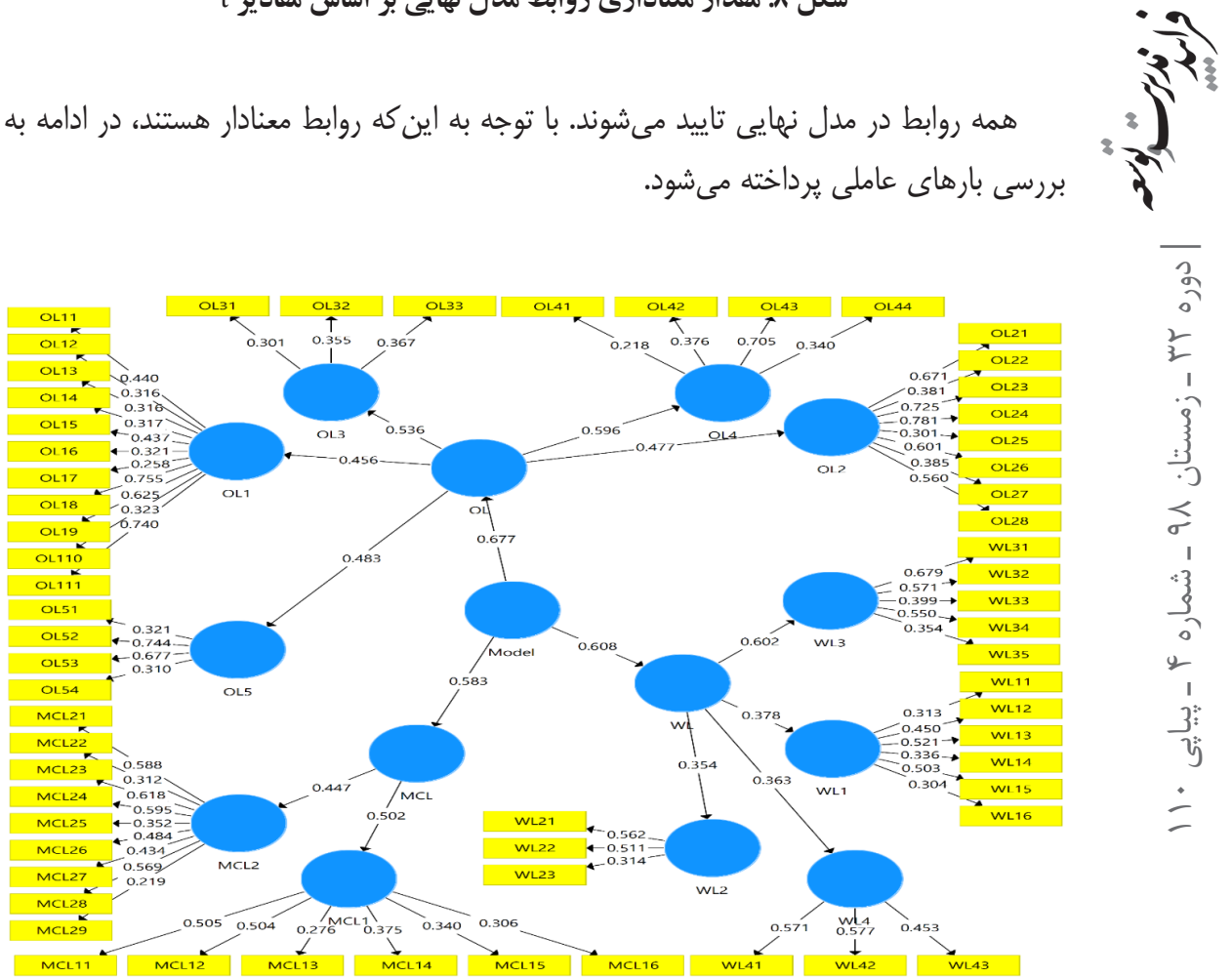

شكل 9: ميزان بارهاى عاملى محاسبهشده در مدل نهايى

منافع سطح كسبوكار داراى بالاترين بار عاملى در مدل است و پس از آن، منافع سطح

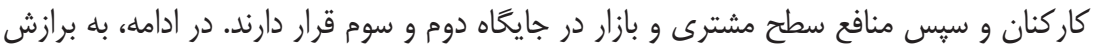
مدل نهايى در نرمافزار Smart PLS يرداخته مى ونود. 
جدول ها ا: شاخصهاى برازش مدل نهايع ثزوهش

\begin{tabular}{llllllcl}
\hline IFI & NFI & CFI & AGFI & GFI & RMSEA & مقاخص \\
\hline
\end{tabular}

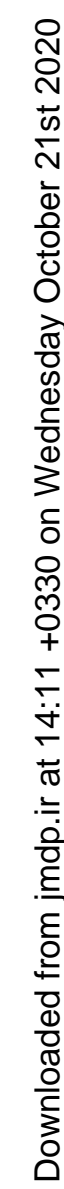

همانطور كه در جدول (1) مشخص است، مدل در حالت كلى داراى تناسب كافى است. بر اساس نتايج بdدستآمده روشن است كه منافع سطح كسبوكار با بار عاملى \&\&V| . يك بخش

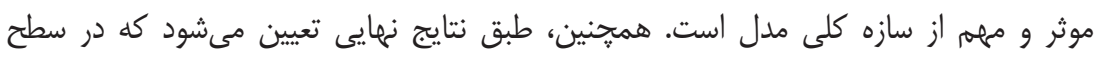

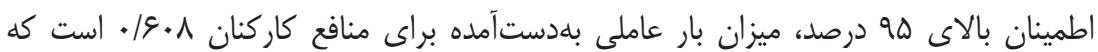

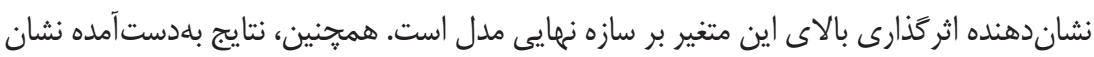

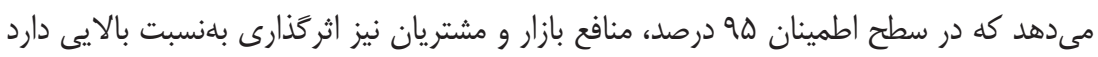
و حضور آن براى سنجش كلى و بررسى نهايى مدل يزوهش الزامى است.

\section{بحث و نتيجه كيرى}

در مجموع از آنجه كه در مراحل يِيشين اشاره شد، مىتوان نتيجه گرفت كه مديريت دانش يك رشته در حال رشد است. با وجود رشد ادبيات مديريت دانش، شكافهاى حياتى درباره اين رشته وجود دارد كه به يزوهش بيشتر نياز دارد (Anantatmula \& Kanungo, 2006). موفقيت در اجراى مديريت دانش تا حد زيادى به سنجش خروجى هاى مديريت دانش بستخى دارد.

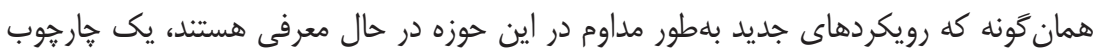

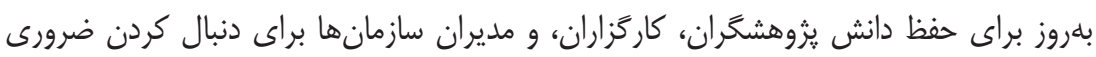

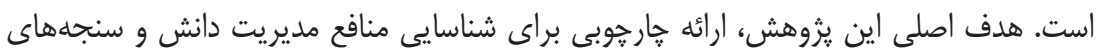

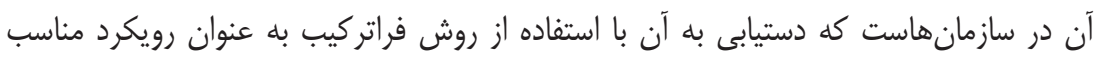

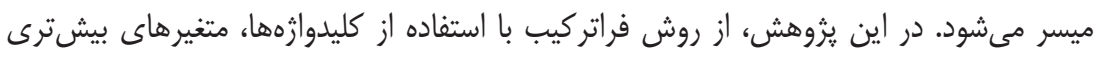

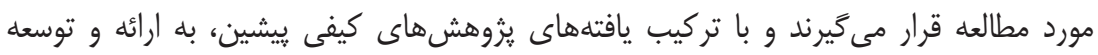

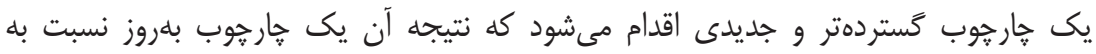
يثوهشهاى ييشين است. بدين منظور، سو منفعت با استفاده از روش فراتركيب شناسايى مى شود و در قالب سه سطح منافع كسبو كار، كاركنان، و مشترى و بازار دستلبندى مىشوند، و پيس از

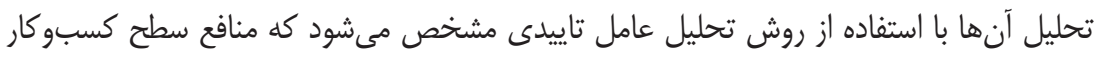


داراى بالاترين بار عاملى در مدل است و پِس از آن منافع سطح كاركنان و سيس منافع سطح

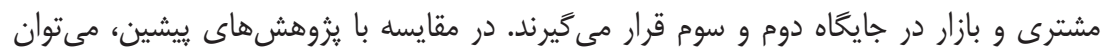

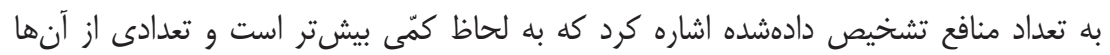
جديد و منحصربdفرد هستند. مولفهها و منافع يافتههاى اين بزوهش، مولفهها و منافع اشارهشده

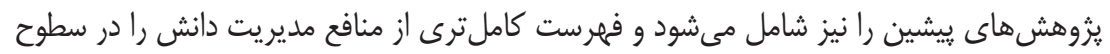

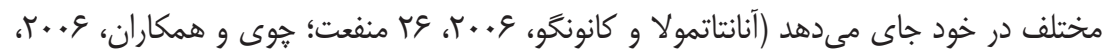

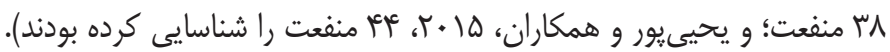

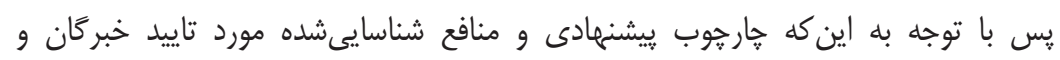

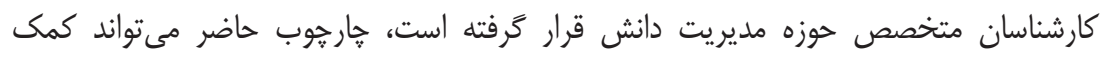

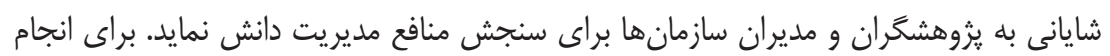

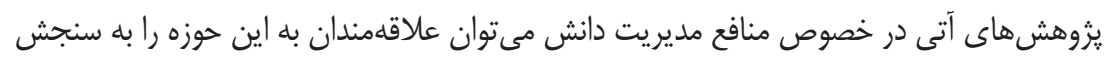

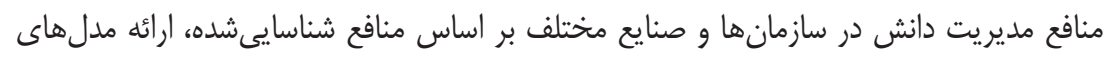

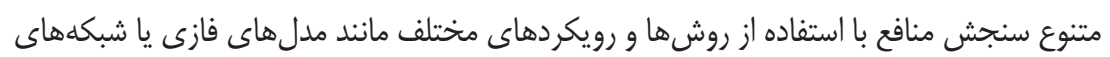

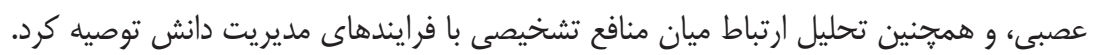

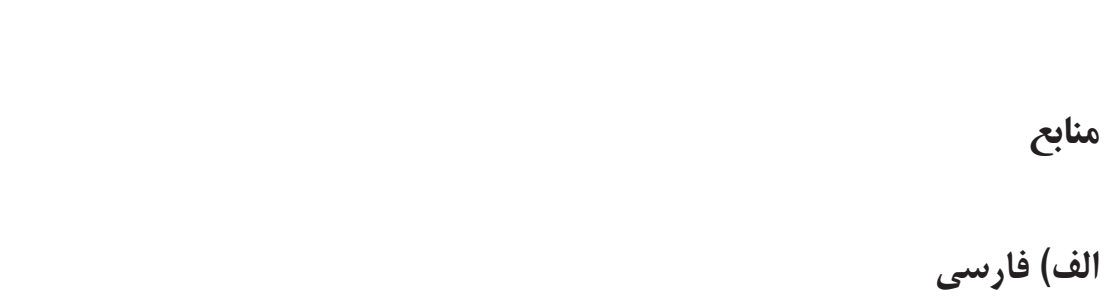

حسين خانى، مهلى؛ رهنورد، فرجاله؛ طاهريور، حبيباله، و حميدى، ناصر (1وسا). مدل ساختارى التزام

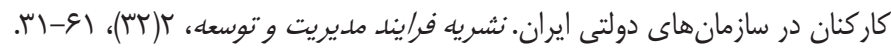

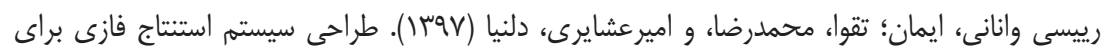

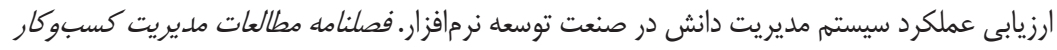

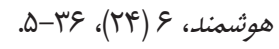

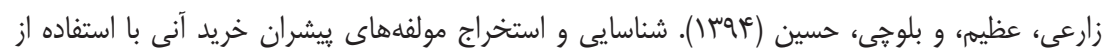

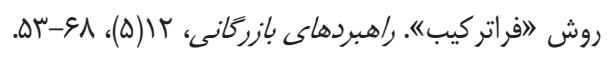

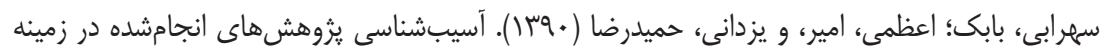

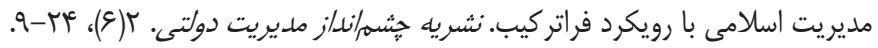

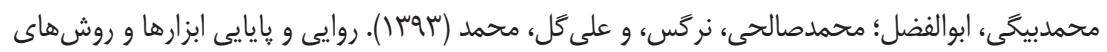

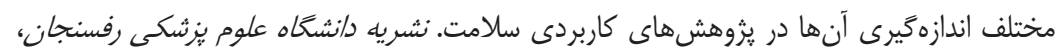

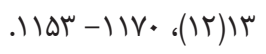




$$
\begin{aligned}
& \text { مرادى، محمد، و سيهوندى، سعيده (4 (1). تاثير استراتزىهاى رقابتى بر پايدارى عملكرد مالى و ريسك. }
\end{aligned}
$$

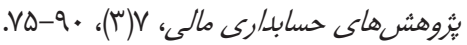

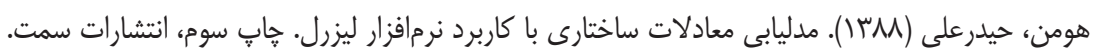

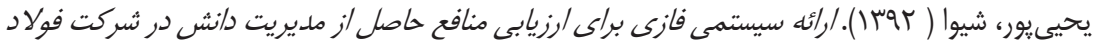

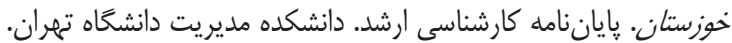

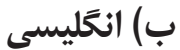

Abualoush, S. H., Obeidat, A. M., Tarhini, A., \& Al-Badi, A. (2018). The Role of Employees' Empowerment as an Intermediary Variable between Knowledge Management and Information Systems on Employees' Performance. VINE Journal of Information and Knowledge Management Systems, 48(2), 217-237.

Anantatmula, V., \& Kanungo, S. (2006). Structuring the Underlying Relations Among the Knowledge Management Outcomes. Journal of Knowledge Management, 10(4), 25-42.

Brahma, S., \& Mishra, S. (2015). Understanding Researchable Issues in Knowledge Management: A Literature Review. IUP Journal of Knowledge Management, 13(4), 43-68.

Cabrilo, S., \& Dahms, S. (2018). How Strategic Knowledge Management Drives Intellectual Capital to Superior Innovation and Market Performance. Journal of Knowledge Management, 22(3), 621-648.

Chong, C. W., Holden, T., Wilhelmij, P., \& Schmidt, R. A. (2000). Where Does Knowledge Management Add Value? Journal of Intellectual Capital, 1(4), 366-380.

Choy, C. S., Yew, W. K., \& Lin, B. (2006). Criteria for Measuring KM Performance Outcomes in Organisations. Industrial Management \& Data Systems, 106(7), 917-936.

Dayan, R., Heisig, P., \& Matos, F. (2017). Knowledge Management as a Factor for the Formulation and Implementation of Organization Strategy. Journal of Knowledge Management, 21(2), 308-329.

De Gooijer, J. (2000). Designing a Knowledge Management Performance Framework. Journal of Knowledge Management, 4(4), 303-310.

Dženopoljac, V., Janoševic, S., \& Bontis, N. (2016). Intellectual Capital and Financial Performance in the Serbian ICT Industry. Journal of Intellectual Capital, 17(2), 373-396. 
Edvardsson, I. R., \& Durst, S. (2013). The Benefits of Knowledge Management in Small and Medium-Sized Enterprises. Procedia-Social and Behavioral Sciences, 81(1), 351-354.

Egbu, C. O., Hari, S., \& Renukappa, S. H. (2005). Knowledge Management for Sustainable Competitiveness in Small and Medium Surveying Practices. Structural Survey, 23(1), 7-21.

Elmorshidy, A. (2018). The Impact of Knowledge Management Systems on Innovation. VINE Journal of Information and Knowledge Management Systems, 48(3), 388-403.

Fallatah, M. I. (2018). Does Value Matter? An Examination of the Impact of Knowledge Value on Firm Performance and the Moderating Role of Knowledge Breadth. Journal of Knowledge Management, 22(3), 678-695.

Ferraresi, A. A., Quandt, C. O., dos Santos, S. A., \& Frega, J. R. (2012). Knowledge Management and Strategic Orientation: Leveraging Innovativeness and Performance. Journal of Knowledge Management, 16(5), 688-701.

Giampaoli, D., Ciambotti, M., \& Bontis, N. (2017). Knowledge Management, Problem Solving and Performance in Top Italian Firms. Journal of Knowledge Management, 21(2), 355-375.

Goldoni, V., \& Oliveira, M. (2010). Knowledge Management Metrics in Software Development Companies in Brazil. Journal of Knowledge Management, 14(2), 301-313.

Gupta, V., \& Chopra, M. (2018). Gauging the Impact of Knowledge Management Practices on Organizational Performance-A Balanced Scorecard Perspective. VINE Journal of Information and Knowledge Management Systems, 48(1), 21-46.

Heisig, P., Suraj, O. A., Kianto, A., Kemboi, C., Arrau, G. P., \& Easa, N. F. (2016). Knowledge Management and Business Performance: Global Experts' Views on Future Research Needs. Journal of Knowledge Management, 20(6), 1169-1198.

Henttonen, K., Kianto, A., \& Ritala, P. (2016). Knowledge Sharing and Individual Work Performance: An Empirical Study of a Public Sector Organisation. Journal of Knowledge Management, 20(4), 749-768.

Hussinki, H., Ritala, P., Vanhala, M., \& Kianto, A. (2017). Intellectual Capital, Knowledge Management Practices and Firm Performance. Journal of Intellectual Capital, 18(4), 904-922.

Jennex, M. E., Smolnik, S., \& Croasdell, D. (2012). Towards a Consensus Knowledge Management Success Definition. Organizational Learning and Knowledge: Concepts, Methodologies, Tools and Applications (403-415): IGI Global. 
Kamhawi, E. M. (2012). Knowledge Management Fishbone: A Standard Framework of Organizational Enablers. Journal of Knowledge Management, $16(5), 808-828$.

Kianto, A., Vanhala, M., \& Heilmann, P. (2016). The Impact of Knowledge Management on Job Satisfaction. Journal of Knowledge Management, 20(4), 621-636.

Lee, S., Kim, B. G., \& Kim, H. (2012). An Integrated View of Knowledge Management for Performance. Journal of Knowledge Management, 16(2), 183-203.

Liu, L., Cheung, C. M., \& Lee, M. K. (2016). An Empirical Investigation of Information Sharing Behavior on Social Commerce Sites. International Journal of Information Management, 36(5), 686-699.

Marouf, L. (2016). The Role of Knowledge Sharing Culture in Business Performance. VINE Journal of Information and Knowledge Management Systems, 46(2), 154-174.

Masa'deh, R. e., Shannak, R., Maqableh, M., \& Tarhini, A. (2017). The Impact of Knowledge Management on Job Performance in Higher Education. Journal of Enterprise Information Management, 30(2), 244-262.

McIver, D., \& Lepisto, D. A. (2017). Effects of Knowledge Management on Unit Performance: Examining the Moderating Role of Tacitness and Learnability. Journal of Knowledge Management, 21(4), 796-816.

Mehralian, G., Nazari, J. A., \& Ghasemzadeh, P. (2018). The Effects of Knowledge Creation Process on Organizational Performance Using the BSC Approach: The Mediating Role of Intellectual Capital. Journal of Knowledge Management, 22(4), 802-823.

Mousavizadeh, M., Ryan, S., Harden, G., \& Windsor, J. (2015). Knowledge Management and the Creation of Business Value. Journal of Computer Information Systems, 55(4), 35-45.

Pina, P., Romao, M., \& Oliveira, M. (2013). Using Benefits Management to Link Knowledge Management to Business Objectives. Vine, 43(1), 22-38.

Rohajawati, S., Sensuse, D. I., Sucahyo, Y. G., \& Arymurthy, A. M. (2016). Mental Health Knowledge Management: Critical Success Factors and Strategy of Implementation. Journal of Knowledge Management, 20(5), 980-1003.

Sandelowski, M., \& Barroso, J. (2006). Handbook for Synthesizing Qualitative Research: Springer Publishing Company.

Shehata, G. M. (2015). Leveraging Organizational Performance Via Knowledge Management Systems Platforms in Emerging Economies. Vine, 45(2), 239278. 
Tabrizi, R. S., Ebrahimi, N., \& Delpisheh, M. (2011). KM Criteria and Success of KM Programs: An Assessment on Criteria from Importance and Effectiveness Perspectives. Procedia Computer Science, 3(1), 691-697.

Tseng, S.-M. (2016). The Effect of Knowledge Management Capability and Customer Knowledge Gaps on Corporate Performance. Journal of Enterprise Information Management, 29(1), 51-71.

Tubigi, M., \& Alshawi, S. (2015). The Impact of Knowledge Management Processes on Organisational Performance. Journal of Enterprise Information Management, 28(2), 167-185.

Vakharia, N., Vecco, M., Srakar, A., \& Janardhan, D. (2018). Knowledge Centricity and Organizational Performance: An Empirical Study of the Performing Arts. Journal of Knowledge Management, 22(5), 1124-1152.

Valmohammadi, C., \& Ahmadi, M. (2015). The Impact of Knowledge Management Practices on Organizational Performance. Journal of Enterprise Information Management, 28(1), 131-159.

Wei, C. C., Choy, C. S., \& Yew, W. K. (2009). Is the Malaysian Telecommunication Industry Ready for Knowledge Management Implementation? Journal of Knowledge Management, 13(1), 69-87.

Yahyapour, S., Shamizanjani, M., \& Mosakhani, M. (2015). A Conceptual Breakdown Structure for Knowledge Management Benefits Using Meta-Synthesis Method. Journal of Knowledge Management, 19(6), 12951390. 